$50 \mid 2019$

Animals in the religion and culture of the Tibetan

Plateau

\title{
Burning the incestuous fox. A Tibetan fumigation ritual (wa bsang)
}

Brûler le renard incestueux. Un rituel de fumigation tibétain (wa bsang)

Daniel Berounský

\section{(2) OpenEdition \\ Journals}

Electronic version

URL: https://journals.openedition.org/emscat/3782

DOI: $10.4000 /$ emscat.3782

ISSN: 2101-0013

\section{Publisher}

Centre d'Etudes Mongoles \& Sibériennes / École Pratique des Hautes Études

Electronic reference

Daniel Berounský, "Burning the incestuous fox. A Tibetan fumigation ritual (wa bsang)", Études mongoles et sibériennes, centrasiatiques et tibétaines [Online], 50 | 2019, Online since 04 March 2019, connection on 13 July 2021. URL: http://journals.openedition.org/emscat/3782 ; DOI: https://doi.org/ 10.4000/emscat.3782

This text was automatically generated on 13 July 2021.

(c) Tous droits réservés 


\title{
Burning the incestuous fox. A Tibetan fumigation ritual (wa bsang)
}

Brûler le renard incestueux. Un rituel de fumigation tibétain (wa bsang)

\author{
Daniel Berounský
}

\section{Introduction}

1 The aim of this paper is to examine the previously neglected textual representations of a highly unusual ritual tradition of burning foxes ${ }^{1}$. It is mostly mentioned as wa sang ("smoke purification ritual of the fox" or "fumigation ritual of the fox") in Tibetan. It might cast some light on the encounter between the old Tibetan ritual traditions and the monastic tradition of Bon. Similar Mongolian texts have been already discussed by a number of scholars, even in a special issue of Études mongoles et siberiennes dedicated to foxes (Beffa \& Hamayon 1984a). It will be pointed out that these Mongolian texts bear clear signs of being translated from the original Tibetan.

2 It must be acknowledged that the following analyses will be based solely on texts, and I have not been able to observe any performance of the ritual so far. Although there is second-hand information about a living tradition of the ritual from the Thewo region of Amdo, where only a few pieces of the hair of a fox were burnt ${ }^{2}$, one must be rather careful regarding this information. The texts presented below speak clearly about the body parts of foxes, such as intestines, bones, head, and so forth, which are burnt during the ritual. The ritual tradition of Thewo was carried out by village lay priests and has been under pressure from the monastic traditions of Bon and Buddhism. It is rather probable that it was such pressure from the religious authorities - for whom any animal offerings represent a barbaric act - that changed the ritual and eventually led to the innocent practice of merely burning fox fur.

3 Following some general information about animal offerings in Tibet, the paper will first briefly summarise the information about the Mongolian ritual texts of Fox-fumigation. After pointing out its Tibetan origin, it will then focus on a recently-published corpus of texts from Dongtrom (lDong khrom) or Datshang ( $\mathrm{mDa}^{\prime}$ tshang ${ }^{3}$ ) in Amdo, where 
some five Tibetan versions related to Mongolian works appear. They are unfortunately extremely illegible and written down phonetically, which impedes a proper understanding. Three other Tibetan texts will then be discussed. Their different contexts demonstrate the fluidity of this tradition, which was even appropriated by the monastic Bon religion. The frequent mention of Nyen beings (gnyan) and the mythical priest Nyen Bon Thangthang Drolba (gNyan bon Thang thang sgrol ba) nevertheless point to the Nyen Collection (gNyan 'bum) as a textual source for the context of the tradition. Despite the great diversity of the individual textual sources, the ritual of burning fox seems always to appear in the proximity of ritual defilement by incest (nal) and the murder of a relative ( $\mathrm{dme}$ ), which represent a pair of the most defiling acts associated with females and males. It is even stated in one of the texts presented below that burning a fox was originally performed to purify these pollutions.

\section{Blood-fumigation (dmar bsang)}

4 Sang (bsang/bsangs) purification is one of the most extensively performed rituals in the Tibetan societies in general. These days it consists mainly of burning fragrant plants mostly juniper twigs. The smell of smoke of juniper is omnipresent in Tibet and laypeople as well as clerics burn juniper daily on "fumigation altars" (bsang khri).

As has been already pointed out by Samten G. Karmay (Karmay 1995, 1998a), despite its easy confusion with Buddhist rituals of burning incense, the autochthonous role of the practice in Tibet differs significantly. While in the Buddhist ritual the incense is commonly considered to be an "offering of smell" pleasing the senses of the deities, its understanding in Tibet relates to the specific idea of ritual purity within the context of the cult of local deities. One of the revealing texts describing a certain underlying idea connected with this ritual and its understanding of purity appears in the extensive Bonpo work Ziji (Gzi brjid $)$ :

Shameless pollution of murder of relative (dme), defiled birth of child (mug), incest (nal) and shamelessness (btsog),

Pollution of bad prediction (than), bad omens (ltas ngan), misfortune (byur) and widowhood (yug),

Defilement of the hearth (thab), enmity (mkhon) and others,

These hit the eyes of gods,

Striking the gods of pure spheres by pollution.

Those who are lords over the base of earth, country and soil are polluted,

Their pollution and the vapours from their mouths,

Will hit the community of human beings,

And poverty, disease, famine and disturbances will arise

In this field of the world,

And various sufferings of misfortune.

For cleansing it (bsang) and bringing purity,

For the healing of all beings,

Within the tradition of Black Waters,

Appeared ways of clearing away (sel) spreading as branches, leaves and petals [...]

6 The text lists the following polluting acts: murder of a relative (dme), defiled birth of a child (mug), incest ( $\mathrm{nal}$ ), shamelessness (btsog), bad prediction (than), bad omens (ltas ngan), misfortune (byur), widowing (yug), defilement of hearth (thab) and enmity (mkhon). Such specific polluting acts "hit the eyes of the deities" of the pure spheres, who are connected with the deities characterized as the lords of places (i.e. local gods). 
The pollution of deities reaches the community of people in the form of "vapours from their mouths" or their "breath" (kha rlangs) and manifests itself as disease, famine, disturbances and misfortune. The raising smoke of fumigation (whether the smoke of juniper or other fragrant plants) is thus used primarily for purification of the polluted deities and simultaneously as a measure for avoiding events that are unfavourable for human communities.

7 In the light of such common and widespread performance of this ritual at the present time, it is rather surprising that instead of fragrant plants, the flesh of an animal should be burnt. In general, animal sacrifices (dmar mchod) are a controversial issue in Tibetan societies influenced by various traditions of Buddhism and monastic Bon. Nevertheless, they are scarcely performed even nowadays, despite the pressure from the monks, and several such cases coming mostly from southern Tibet have already been described in scholarly literature ${ }^{5}$. But to the best of my knowledge, the discussions of sang rituals during which the animal is burned has remained a neglected topic.

Katia Buffetrille has recently presented an example of such a ritual from Thrika (Khri $\mathrm{ka}$ ) in Amdo, during which the body of a goat was burnt ${ }^{6}$. Another reference appears in connection with the famous Lurol (Klu/Glu rol) festival taking place annually in localities near Rebkong, where it is described that the flesh of an animal is partly burned as an offering and part of its body is boiled and consumed by people ${ }^{7}$. There is another recent reference from Amdo which speaks about the burning of the whole bodies of five roosters in the context of empowering a local village deity against the divinity of the neighbouring village ${ }^{8}$.

One can, nonetheless, find some general and not very illuminating notes about such practices in Tibetan literature. In the texts, it is called simply marsang (dmar bsang, i.e. "red smoke purification" or "blood-fumigation") and no description of the ritual is usually given". An exception seems to be a very brief account of it given by Zhabkar (Zhabs dkar, 1781-1851), a well-known master from Amdo, who describes with predictable distaste the abundant practices of animal sacrifices which took place in his native region during his lifetime, including marsang (Zhabs dkar tshogs drung rang grol 2002, p. 518 ${ }^{10}$ ):

Or, even the bloody heart with arteries is taken from the trunk of the living body [of the animal]. Still beating on the hand, it is placed into the scorching fragrant plants (bsang) when performing the "red smoke purification" and the offering of blood and flesh [...]

Zhabkar thus describes the "blood-fumigation" as a ritual during which the heart is pulled out from the living animal and burned amid fragrant plants. The fact that only the beating heart of the animal was burnt differs from the references to burning parts or whole bodies of animals mentioned above.

Concluding this introduction, it is apparent that there used to be a purification ritual of burning either the entire bodies of animals, or solely their heart, which continues, if in a very limited form, to the present time. All the known references presented here located such rituals in north-eastern Tibet (Amdo $\left.{ }^{11}\right)$. 


\section{Mongolian texts of fox-fumigation (Ünegen-ü sang)}

12 The obvious reason for the following digression to Mongolia is that since the 1970's several similar Mongolian texts have been discussed by eminent scholars of Mongolian studies.

The discussion started with two short and rather similar versions from Ordos published by Henry Serruys (Serruys 1970, version 1 and 2) in the journal Zentralasiatische studien. It was in the same journal where translations and editions of other Mongolian versions of the text were subsequently presented by Walther Heissig (Heissig 1976, version 3, kept in Budapest) and Charles Bawden (Bawden 1976, 1978, two similar versions 4 and 5 from Ulaanbaatar and another similar version 6 in Oirat script from Ulaanbaatar). It was discussed then by Marie-Lise Beffa and Roberte Hamayon in a French volume dedicated to the perception of foxes in Central Asia (Beffa \& Hamayon 1984b). Later in another volume dedicated to foxes in Central and Eastern Asia and published in Germany, another text was presented by J. Coloo (Coloo 2001, version 7) and three versions housed in St. Petersburg were discussed and translated by Alice Sárközi and Aleksei G. Sazykin (Sárközi \& Sazykin 2001, versions 8, 9, and 10). To my knowledge, no Tibetan version of such ritual texts has been the subject of discussion so far.

Thus, some 10 Mongolian texts, which come from virtually all regions of Mongolia from west to east (Sárközi \& Sazykin 2001, p. $76^{12}$ ) were made available. Despite the variety of the known versions, it is still clear that all of them share the core of their content, which remains quite puzzling. Most of the authors saw the texts as rather inconsistent and full of abrupt expressions.

Many of the questions already discussed have been related to the possible origin of the text. Serruys considers the ritual to be "shamanist", but Bawden does not see any particular shamanist elements in it. Walther Heissig points out that some parts of the text have different inspirations. He recognizes the Indo-Tibetan legend, pre-Buddhist hunting cults, Buddhist purification rites and Buddhist protective rites. Hamayon and Beffa see the text in the context of the struggle between Buddhist clergy and shamanists in Mongolia. They also have doubts as to whether the fox was burnt, since the idea is indeed rather strange. The Mongolian versions do not contain any clear mention of the fox being burnt, which makes the title of the text (fox-fumigation) rather enigmatic. Sárközi and Sazykin raised doubts about the Mongolian background of the text, saying that the whole idea could come from Tibetan or Chinese folklore (Sárközi \& Sazykin 2001, p. 78).

16 The opening parts of these Mongolian texts contain a myth on the origin of the foxes followed by a mythical narrative about the origin of the ritual. Although it has never been done so far, the Mongolian texts available could be apparently sorted into the three loose groups, which I will call "redactions" in a rather broad sense. All the texts within one redaction are, however, not always the same. In some versions within the mentioned redaction there appear different wordings and names listed. But these "redactions" have much more in common than not and the flow of their narration differs marginally. 


\section{First redaction}

17 Versions 1 and 2 (Serruys 1970) contain very brief renderings of the myths. After paying homage to Göngdzii (this was mistakenly rendered as "Jug" by Serruys) there appear introductory verses describing purification of the vertically viewed world. There follows a brief text about the opening of the door of the fumigation, which runs upwards like the river of Snowy Mountains. The myth is only very brief. It mentions the King of Birds (rendered as Garudi) uniting with "companions" or "relatives", nine foxes being born from such polluting (i.e. incestuous) intercourse. People killed the foxes and made them into an offering.

\section{Second redaction}

Another group of manuscripts (versions 3, 8 and 9, Heissig 1976, Sárközi \& Sazykin 2001) contains a more elaborate myth. Following similar parts concerning the offering coming upwards like the river, a character called the Six-Saint-Father-God appears on the scene together with his three wives $^{13}$. From their polluting (i.e. incestuous) intercourse nine foxes were born. The names of the foxes are similar to the names of the wives, apparently originally Tibetan ${ }^{14}$. Pollution appeared in the world together with them.

In the next part the texts speak about burying Mother (probably of humans, but it could be taken also as a mother of the foxes). Son of the water-spirit (Mo. luus, Tib. klu; version 8 has "dragon") sends a fox with a message not to bury the mother on the top of the water-spirit. But the fox forgets the message. Thus, the Mother is buried on the top of the water-spirit and the subsequent contamination brings misfortune to several ancestor figures. Two characters called Ridu and Ravadu become stupid ${ }^{15}$, the wife of the Determiner-King becomes blind, the King deaf, and their son goes mad ${ }^{16}$. A Günzei Khan (version 8) or sorcerer (taraniči qayan, versions 3 and 9) is summoned. He advises that the fox be caught. After it has been caught, the fox pleads not to be killed; but that if it is to be killed, this should be done by piercing its neck with a golden pin according to the texts. The fox then names parts of its body which, through fumigation, purify corresponding parts of the world.

\section{Third redaction}

20 The third group of texts comprises versions 4, 5, 6, 7 and 10 (Bawden 1976, 1978, Coloo 2001, Sárközi \& Sazykin 2001). All of them seem to be the most Buddhicized, which is apparent even from the initial homage to the Three Jewels (versions $4,5,10$ ) or Mañjuśri (version $6,7^{17}$ ). The main difference in the first part dealing with the origin of foxes lies in the fact that all the versions univocally speak about the Six-SaintFather-God (or Father of Six [types of creatures]) and the King of Birds (Garuda), who is meant to be the same being. He mated with his own daughter (or "girl of mine"). The wives altogether disappear from this redaction. From their union nine foxes are born with names that are sometimes similar to those found in the second redaction, but in all versions of this third redaction there also appear among them "Black-mouthed" and "Black-tailed" foxes, rendered in Mongolian (unlike the mere phonetic transcription of the previous names). 
21 In the next part of the myth there suddenly appear three boys from one mother: Tibetan, Chinese and Mongol. Their mother was polluted (it is not clear why) and Seven Fierce Stars (appearing here instead of the son of the water-spirit or dragon) send a fox with a message not to bury their mother amid the Seven Fierce Stars. However, the fox forgets about it and the sons bury their mother there. Consequently, the White Mountains of Tibet, Mt. Bumbura (i.e. Machen Pomra) are defiled, the gods no longer provide protection and say wicked words to the masang ${ }^{18}$. The three brothers become poor and their cattle reduced. Only then do the texts speak about a blind Creator Mother and a deaf Determiner-King as in previous redactions, but unlike the previous versions a King of Birds who has his mind blocked is mentioned.

Then, again in all versions of this redaction, Mañjuśrī appears and advises them to pray to the Seven Fierce Stars (doloyan doysin odud; only version 6 says that these stars are lords of water-spirits at the same time). The Seven Fierce Stars advise to invite Güngzi Khan (Qonqtsa, Günzüd, etc.) who in turn orders the fox to be caught. The fox then similarly pleads not to be killed. If he is to be killed, this should be done with a golden hook (version 6, version 10: golden pin, versions 4, 5: golden silk). The fox then similarly speaks about fumigation of the world by its bodily parts.

Before surveying the various Tibetan versions that mention the ritual of "fox fumigation", it should be stressed here that even the Mongolian texts summarized here bear traces of the Tibetan tradition. There could be some specific Mongolian elements present in the texts ${ }^{19}$, but the core of them certainly bears witness to their Tibetan origin. Besides such indications as Tibetan-sounding names (of foxes and the wives of the progenitor), it also mentions Mt. Machen Pomra, Güngzi Khan (Güngzii, Güngzei, Qonqtsa, Günzüd, etc.) - who is the Chinese king Kongtse, figuring as the author or protagonist of a number of Tibetan texts related to astrology in Bon and so-called Buddhist traditions ${ }^{20}$.

But by far the most convincing argument for the Tibetan origin of these texts concerns the character of the so-called Father of Six [types of creatures] or Six-Saint-Father-God mentioned at the beginning of the Mongolian texts ${ }^{21}$. None of the above-mentioned authors has recognized that this name is an attempt to translate literally the name of the ancestor figure of the Tibetan texts, a heavenly being Cha (phywa) known in variety of spellings as Yabla Dedrug (Yab lha sde drug, lit. "Father God - Six Divisions", also spelt Yab lha bdal drug, Yab bla brdal drug, Yab bla bdag drug, etc. ${ }^{22}$ ). As an ancestor he is known to Dunhuang documents and figures in a number of texts, but solely in Bonpo works. So far, I have never come across a "Buddhist" myth mentioning him. This fact makes clear that the model for the Mongolian tradition was a text that could be ascribed to the Bon tradition (in a very broad sense of its various meanings). We are clearly dealing here with a Mongolian ritual tradition stemming directly from the textual sources of Bon.

The name Yabla Dedrug also explains the confusing and rather illogical and puzzling mention of him as the King of Birds (or Lord of Birds), which at least in some editions appears to be the same being as Father of six [types of creatures]. In the Tibetan texts this ancestor sometimes bears the title Lord of the Cha (phywa rje). The Cha are heavenly beings who are ancestors of the Tibetan kings according to a number of 
mythological texts. The syllable phywa (written often also as phya) is rather similar to the syllable bya meaning "bird". The hypothetical Mongolian translator with an apparently limited knowledge about Bonpo mythology probably understood it as bya rje, meaning "Lord of Birds" (instead of the correct phywa rje, "Lord of the Cha"). This is an additional argument for the Tibetan origins of these ritual texts. As will be apparent from the lines below, the enigmatic Seven Fierce Stars or "water spirits" stand for the Tibetan beings called Nyen (gnyan), who are not known to Mongols.

\section{Tibetan texts from Dongtrom (IDong khrom)}

Some five Tibetan texts, whose content is very close to the Mongolian versions, have recently been published in the series of 30 volumes containing reproductions of the Tibetan texts held privately in the Dongtrom (IDong khrom ${ }^{23}$ ) locality of north-eastern Tibet. The title of the whole publication is Worthwhile to Behold: Collected Ancient Texts from Datshang of Domay ( $m$ Do smad mda' tshang yul gyi mna' dpe phyogs bsdus mthong ba don ldan) and it presents texts of a ritual tradition outside monastic Bon with substantial elements of astrology. The titles of the texts dealing with foxes, which are clearly interrelated, are mostly given as The Long-Nosed Fox (sNa ring wa; written with apparent scribal errors as Na res wa, Na ris wa, Nas reng wa, etc.).

These texts are still used during the rituals performed in the areas of Thewo (The bo) and Phenchu ('Phan chu) of Amdo. They are included in the larger collection of minor rituals for diverse purposes called habitually zhag gcig ma, i.e. "rituals performed within a single day". These have no fixed date of performance, but could be commissioned at any time by lay religious specialists called leu $\left(l e^{\prime} u\right)$. During the ritual, only a few hairs of the fox are usually taken from the traditional fox-fur hat and burnt amid the smouldering plants used in sang ${ }^{24}$.

The discovery of these Tibetan texts would normally give researchers a chance to compare these texts closely with the Mongolian versions to see possible additions by the Mongols, the original meanings, and so forth. But even the Tibetan titles given above indicate that the spellings in these texts are corrupted to such an extent that they pose insoluble problems concerning the correct reading. Indeed, they go far beyond any other case of misspelling in Tibetan texts that I have ever observed. Due to this limitation, the following translation presents only the opening part on the origin of foxes with suggested corrections paradoxically also facilitated by the apparently corrupt Mongolian translations. This part represents a relatively comprehensible text; but it would be impossible to render what follows without venturing into fantasy, lacking any firm basis. To illustrate the level of corruption of the text, the original reading of one of the texts is added with my suggested amendments of it based both on Mongolian versions and the rest of the manuscripts from Dongtrom:

How did these long-nosed foxes originate?

In the past, at the beginning of creation,

The Lord of Cha, Yabla Daldrug,

And Khamo Yarlha Chimo, the two,

Acted with the pollution of murder (dme) and incest (nal),

And thus, seven [nine ${ }^{25}$ ] incestuous related foxes appeared:

The eldest [brothers] were Khakar and Mokar, the two,

Then Khashug and Mushug, the two, 
[then Khadreg and Mudro, the two,]

The youngest were Khanag and Mugnag, the two.

As their sister Cangmamen came to existence as the seventh [ninth].

At that time and aeon,

Seven brothers [appeared] from the Nyen,

Thideri and Gyalderi [appeared] from people,

Those two were sons descended from a single mother [...]

Figure 1. The title page of the text on the "Long-nosed Fox" entitled Bon 'di nas sna ring wa yi dbu lagstho (reading emended)

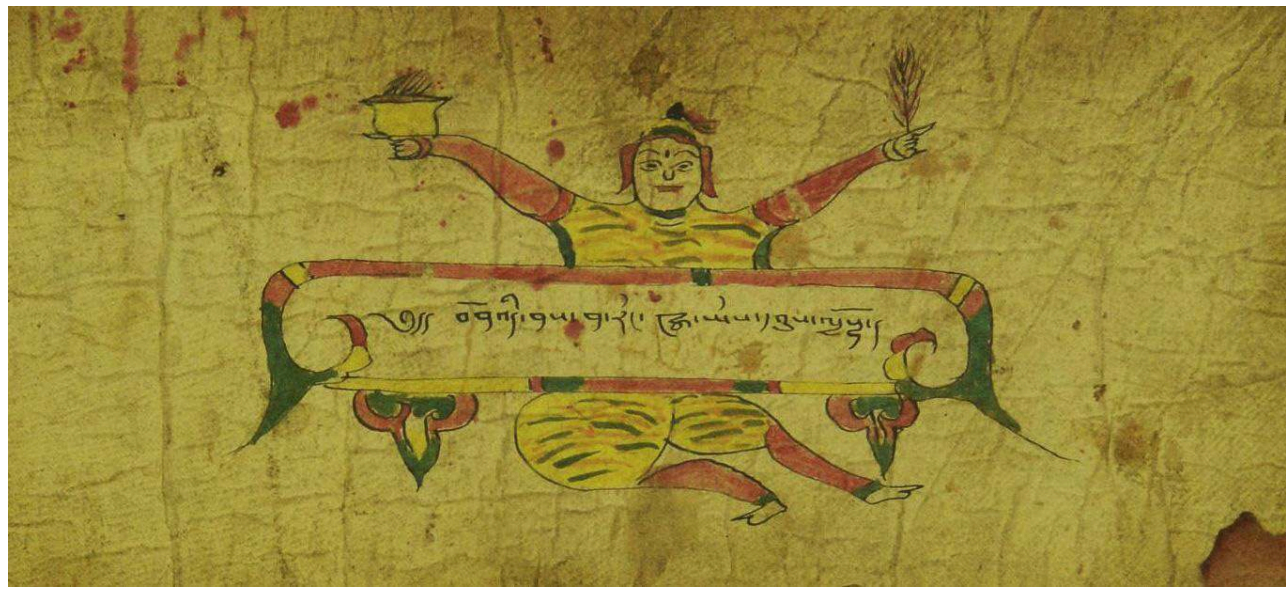

From 'Brug thar (ed.), mDo smad yul gyi gna' dpe phyogs bsdus mthong ba don Idan, vol. 26, p. 1.

(c) Gansu wen hua chu ban she

Figure 2. The text on the origin of foxes emended and translated in the article

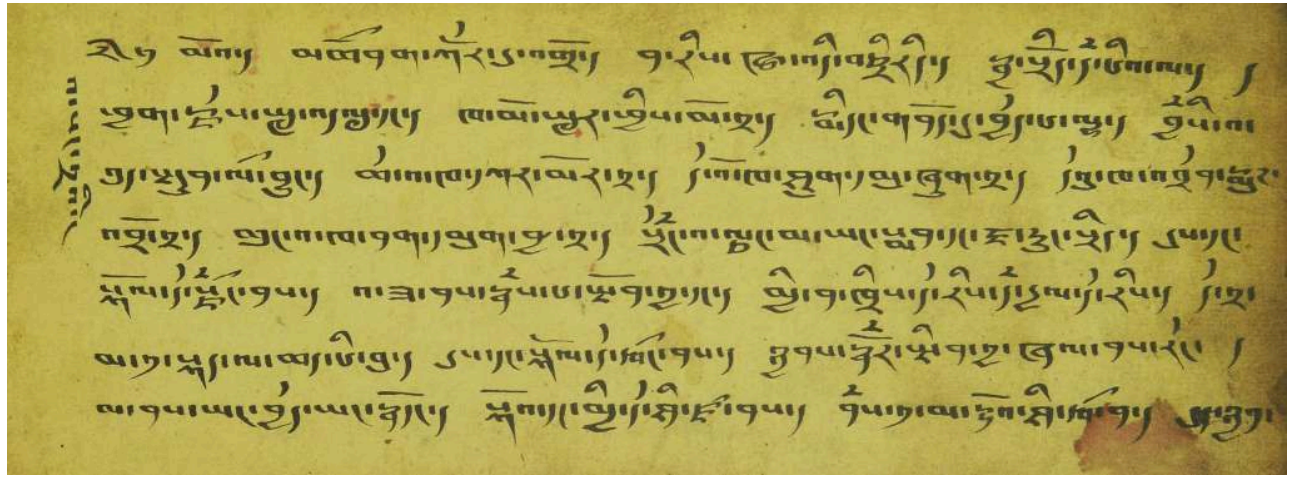

From 'Brug thar (ed.), mDo smad yul gyi gna' dpe phyogs bsdus mthong ba don Idan, vol. 26, p. 3.

(c) Gansu wen hua chu ban she

\section{Original text}

na ris wa'di bc+ri+ri/

s+bya sri+o+d dam pi' la/

phyag rjes $y+y$ 'dl $+r+u$ dang/

kha mo $y+y+r$ phyis mor 2/

smid+d gnod du byed pa lha/

gnod gis 'a 'u spun $X^{26}$ g+hyung/

che 'a kha kar mo kar 2/

de'u la shug dmu thug 2/

chung 'a kha nag dmug nag nyis/

srid mo 'a lcang ma sman dang $X$ rung srid/ 


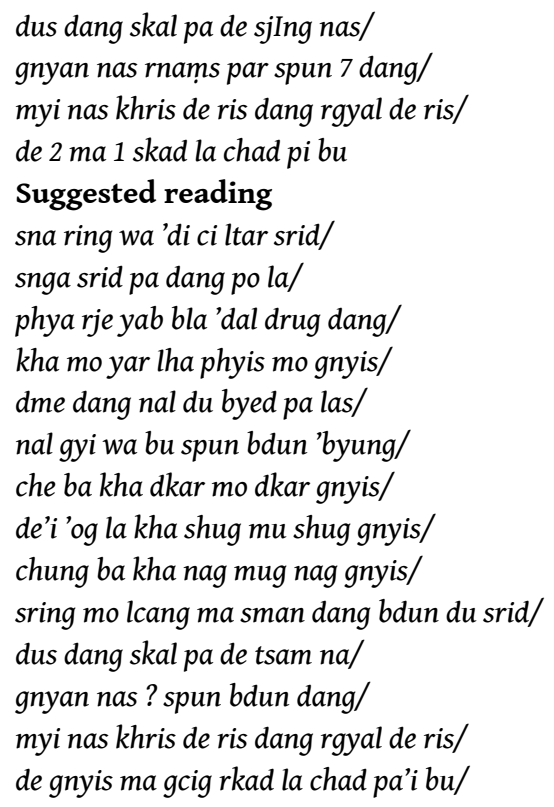

To sum up, both in the Mongolian versions and in the largely corrupt Tibetan versions, the foxes appear from an incestuous relationship that Yabla Daldrug has. Even from the hardly comprehensible Tibetan versions it is obvious that they mention the burial of a certain mother. The main reason for the ritual is the pollution of the Nyen by the corpse of the mother figure, probably the mother of both Nyen and original people, though the Mongolian versions do not mention Nyen beings at all. The "Seven Fierce Stars" or "water-spirits" of the Mongolian texts are obviously Nyen beings, who are not known to Mongols. The meaning of the Tibetan expression Nyen (gnyan) designates a special class of beings, but can mean "fierce" at the same time.

\section{Drawing the ritual into monastic Bon}

A text to be found in the New Collection of Bon Katen Texts, entitled Pronouncement of the Secret of the Smoke Purification by [Means of the] Fox [Called] the Voice of the Cuckoo ${ }^{27}$, represents an attempt to integrate this ritual into the monastic tradition of Bon and to make it compatible with its doctrine. The text itself does not contain particular details concerning the performance of the ritual. Its opening is styled as sādhana (grub thabs), during which the performer is identified with Kuntu Zangpo (Kun tu bzang po); a deity "transcending all purity and defilement ${ }^{28}$ ":

I am Kuntu Zangpo (All-Good),

There is All-Good non-existence of "Me" (i.e. "self"),

Kuntu Zangpo is the source of elixir,

Kuntu Zangpo is the source of poison,

Kuntu Zangpo is the "basis of all" (kun gyi gzhi),

The entirely pure "basis of all" devoid of defilement [...] 
Figure 3. Depiction of Thangthang Drolwa (Thang thang sGrol/Khrol ba), a mythical specialist dealing with Nyen

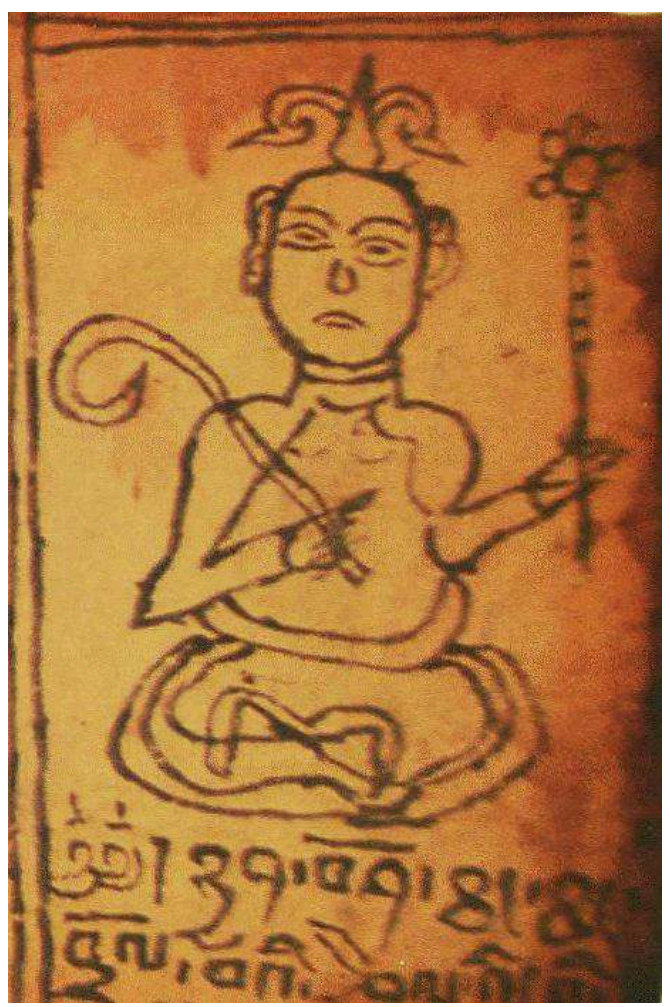

From 'Brug thar (ed.), mDo smad yul gyi gna' dpe phyogs bsdus mthong ba don Idan, vol. 21, p. 246

(c) Gansu wen hua chu ban she

The text does not contain any detailed myth on the origin of the ritual, but it mentions the personage of ritual specialist Nyen Bon Thangthang Trolwa (gNyan bon Thang thang khrol ba) as an ancient founding figure of this ritual, and such a fact will be of certain importance. This mythical ritualist apparently specializes in dealing with Nyen beings (hence he is a Nyen Bon, a ritual specialist dealing with Nyen). That the whole tradition appears in the context of the ritual propitiation of Nyen beings is further confirmed by the text listing several categories and names of Nyen, who are purified by the smoke (bsang) rising from the apparently burned fox. The specific pollution to be purified is mentioned as "pollution of murder" ( $\mathrm{dme}$ ) and pollution nol (mnol, which, as will be seen later, is in this case somehow related to nal, "pollution of incest", and in this text, it will be translated as "fornication", but in the specific Tibetan sense ${ }^{29}$ ):

Kyai! Now to the sun of the origin of the world,

And to the Nyen of the origin of the world the purification is offered,

At the moment of the sun rising in the sky,

There is no place of unclarity or obscurity of knowledge,

Offering the cleansing purification by the fox of the origin of the world,

There is no place with pollution of murder ( $r m e$ ), fornication (mnol), and impurity,

May all pollution of murder and fornication be purified!

The place of the primaeval origin in the past

Is the country of the Nyen - Phomo Serteng,

Where the Nyen Bon Thangthang Trolwa resides,

Thinking with love for the benefit of sentient beings,

For the spread of the teaching of Bon,

And for taming the pernicious demons Dü (bdud) and Sin (srin), 
He performed the miraculous rituals of primordial wisdom,

And made the sphere of the Nyen of origin of the world spread and the sphere of

people increased.

During that past good creation,

The fox-purification was offered to the Nyen of creation,

The ablution liquid (tshan khrus) was offered to the Nyen of creation,

May the entire sphere of gods be purified!

May the entire sphere of Nyen be purified!

May the entire sphere of people be purified!

Yet one of the most surprising features of this text is found in its colophon, which says: "This narrative of the origin of smoke purification and lustration that cleanse the pollutions of murder ( $\mathrm{dme}$ ) and fornication ( $\mathrm{mnol}$ ) was composed by the sage of the priests Sherab Gyaltshen in the hermitage of Menri ${ }^{30 "}$. It thus ascribes the composition of the text to the important reformer of monastic curriculum of the Bon monasteries and founder of Menri (sMan ri) monastery Sherab Gyaltshan (mNyam med Shes rab rgyal mtshan, 1356-1415), whose role for monastic Bon could be compared to that of Tsongkhapa (rJe Tsong kha pa) for the Gelugpa tradition. One can only speculate whether such information on the authorship is trustworthy or should be better seen as an effort to legitimize the ritual within the monastic teachings. Whatever the case, Sherab Gyaltshen was a native of eastern Tibet (rGyal mo rong), which is perhaps a more pertinent fact.

\section{A text from the ritual cycle Bringing All Disturbances of the Triple Thousand World to Harmony}

The second text appearing in the New Collection of Bon Katen Texts is entitled Blue Smoke Purification by Fox [from the Ritual Cycle of] Bringing All Disturbances of the Triple Thousand World to Harmony (sTong gsum 'khrug pa yo bcos kyi wa bsang sngon mo bzhugstho, Katen, vol. 84, pp. 95-102). Although there is no colophon present in this particular text, it is a part of the 84th volume of the New Collection of Bon Katen Texts, which contains a corpus of the texts generally known as the Remedying the Agitation of Sadag (Sa bdag 'khrug bcos). The whole corpus was allegedly revealed by Gode Phagpa ('Go sde 'phags pa, alias gShen gsas lha rje, b. 1215), a Bonpo master living in the locality of eastern Tibet specified as Ragtrom (Rag phrom, cf. Karmay 1972, p. 175). The rock from which the "treasure" (gter) was retrieved is said to be in one of the valleys in Dzingshog township ('Dzin shog shang) of Palyul County (dPal yul rdzong) south of Derge (sDe dge) according to the recent account based on oral tradition ${ }^{31}$. The corpus of texts revealed by Gode Phagpa contains scriptures, which are also present among the abovementioned collections from the areas of Thewo (The bo), Phenchu ('Phan chu), Zitsa Degu (gZi rtsa sde dgu) and Dongtrom (lDong khrom) ${ }^{32}$. This suggests some interrelationship between them, although it is impossible to specify exactly how the texts known from the north-eastern Tibet appeared in the Kham area of Palyul in the $13^{\text {th }}$ century.

This informative text opens with a rather incomprehensible passage depicting the origin of three "fumigation foxes" (bsang gi wa) from their father and mother, related to the sky and the earth respectively ${ }^{33}$. These three foxes are characterized as being of strong desire ( ${ }^{34}$ ) and with long noses (sna ring); the latter designation is used in the titles of some of the texts introduced above. The bodily parts of the fox are then enumerated, stating in a repeated phrase that the corresponding Nyen beings are 
purified by them. Thus the fur of the fox purifies the Nyen of trees, the bones of the fox purify the Nyen of rocks, the intestines of the fox purify the Nyen of roads, etc. Although the text does not mention the original ritualist Nyen Bon Thangthang Trolwa, as was the case of the previous text, the whole ritual is again similarly immersed in the worship of Nyen beings.

The text follows then with a brief and rather surprising myth on the origin of the ritual ${ }^{35}$ :

Where did the smoke-purification of lords of the soil (sa bdag), Nyen (gnyan) and serpent spirits $(k l u)$ by the fox originate in the past?

In the past, in the heights of the sky,

Dwelled the owner of ambrosia (bdud rtsi),

The Lord of the Cha (Phywa), Yabla Dedrug (Yab bla bde drug),

It was he who spread $^{36}$ the pure ambrosia,

[It was he who] made ${ }^{37}$ the pure ambrosia [appear] on the earth as a flower grown

there.

The pure ambrosia fell down onto mother earth,

A flower of ambrosia grew at the place where the ambrosia fell,

From that flower of ambrosia,

[The ambrosia] proceeded to the nest of a miraculous bee ${ }^{38}$,

That ambrosia proceeded into the nest of the bee,

It was seen by a fox in the darkness,

The fox ate up the ambrosia of the nest of the bee.

By the virtue of fox's eating up the ambrosia,

The flower manifests in its body,

The flower manifests in its teeth,

Ambrosia [...] $]^{39}$

And thus, the fox has the ambrosia.

All the uneasiness of the lords of soil, serpent spirits and Nyen is purified by it,

The smoke from burning of the flesh of the fox,

Proceeds to the sky,

And purifies all Nyen of the sky,

The flames enter the space in-between,

And purify all Nyen of the intermediate space,

The parts [of the fox ${ }^{40}$ ] enter the soil,

And purify all lords of soil, serpent spirits and Nyen of the earth.

This rather surprising myth renders the foxes as becoming, quite incidentally, saturated by the ambrosia (bdud rtsi) owned originally by the ancestral figure Yabla Dedrug, the lord of the Cha (Phywa) beings of the sky. But the surprise does not stop here, since in the following part there is suddenly a dramatic turn ${ }^{41}$ :

At this moment, a part of the flesh of the fox is first dragged and then cast down.

The following is pronounced:

Kye! May this fox not be burned entirely!

If this fox were burnt entirely,

The flesh of all kinds of dirt weakened would be eaten by a fox (?),

As for the corpse of a man, by a fox it would be dragged,

As for the corpse of a horse, by a fox it would be harmed (?),

And thus do not burn the entire fox!

Cast down the kidneys of the fox!

Cast down the kidneys of dirt!

Cast down the kidneys of pollution of incest!

Cast down the kidneys of pollution of murder!

Cast down the kidneys of famine! 
Cast down the kidneys of the Dri demons [causing the] death of males!

Cast down the kidneys of the Dri demons [causing the] death of females! ambivalent beings by the text. Their polluted nature is given by their origin (in the texts introduced above and below it is often specified as "incestuous" [nal]), and the types of pollution are apparently kept in the part of their body related to their kidneys. At the same time, their ability to purify is given by the presence of original "ambrosia" in the other parts of their bodies. By burning them, the types of pollution (again, mostly specified as pollution due to murder [ $\mathrm{dme}]$ and incest [nal]) would be purified by the smoke rising from the burned fox; in contrast, the part containing the kidneys should be cast down.

\section{Text on smoke purification by the fox, the monkey and the badger from Phenchu ('Phan chu)}

Another anonymous text to be presented here brings a further disturbing amount of incoherence in its details. Its title is The Fox, the Monkey and the Badger; the Three (Wa sbrel grum gsum dbu lagstho) and the concluding part is missing from the text. It was photographed in the village of Sayul (Sa yul) in the Phenchu ('Phan chu) region of north-eastern Tibet by Ngawang Gyatso, who generously made it available to me. The text comes from a collection of ritual texts designated as leu (le'u), still sporadically surviving in this part of ethnographic Tibet, which are also a subject of Ngawang Gyatso's research (see Ngawang Gyatso 2016b). The area of Phenchu is not very far from Dongtrom (lDong khrom), from which the first Tibetan texts resembling the Mongolian versions come.

This time the badger, the monkey (and a bird as well, according to the text itself) are mentioned along with the fox as the subject of burning in order to purify the pollution caused by the events following the creation of the world. The opening parts of the text contain the rendering of such events, which should be subsequently remedied via the ritual ${ }^{42}$ :

Kyai!

From the primeval void of nonexistence,

A bit of original existence came into being,

A wind of creation was formed from it,

From the white wind a Conch-Shell Man came into existence,

From the blue wind a Black-Headed Man of the [realm of] Wishes came into

existence,

From the black wind a Black Man of the Ngam [realm] came into existence,

From the red wind an Old Man and Woman of copper and iron came into existence.

They were killed by the golden hail of the black wind (?),

Nobody buried the dead ones,

The black demon Dre of pollution of murder,

And the golden demon Serag (?),

Brought sorrow to the Lhekar, the Conch-Shell Man,

They opened the gate blocking [demons].

A great spleen and violence arose,

The lower gate was opened,

The upper demons Dü were about to [act as] ice broken into pieces,

[The lower demons Dü were about to act as boiling water ${ }^{43}$,]

The demons Tsen of the middle region were about [to act] as swirling wind, 
The gates of demons Dü and Tsen were open to be crossed,

The voice of birds was evil in the sky,

[The voice of mice was evil on the earth ${ }^{44}$,

The [voice of] owl was wild at the rock.

41 To recapitulate briefly: during the creation of the world, four classes of beings are created from the different winds: 1) a Conch-Shell Man (representing the divine realm), 2) a Black-Headed Man of the realm of Wishes (representing the original people), 3) a Black Man of the Ngam realm (representing demons) and the vaguely-described 4) old Man and Woman of copper and iron. The last listed ones are killed by demons without being buried, and this act leads to the unrestricted influx of demons into the world, namely to the "pure" realm of the Conch-Shell Man.

This situation is then remedied by the mythical ritualist of the Conch-Shell realm named Dungbon Serbunyer (Dung bon ser bu gnyer, Ritualist of the Conch-shell realm; the one dealing with wind) who, according to the text, performs a ritual named the "great purification by burning" (sregs sel chen $\mathrm{po}^{45}$ ):

Dungbon Serbunyer,

Spread a conch-shell cushion,

Near the conch-shell rock,

Poured a turquoise medicine,

Set up a powerful golden stone.

The white conch-shell monkey,

With turquoise eyebrows.

The conch-shell bird,

With turquoise wings,

The conch-shell badger,

With turquoise eyebrows,

The conch-shell fox,

With turquoise mouth and claws,

All of them were decorated with gold, silver, conch-shell and agate,

Some of them were decorated with copper and iron,

Some of them were decorated with tiger and leopard [fur].

The conch-shell [...]? (g.yar po),

The turquoise [...]? (thugs re),

And golden sword,

Were established as supports for the deities,

And were attached to the right side of the red copper pig,

The Bon performed the ritual (gto).

A cap was taken from the head of Conch-Shell Man,

And was placed on the heads of the fox, the monkey and the badger,

The shoes were taken from the feet,

And put on the feet of the fox, the monkey and the badger,

[The fox], the monkey and the badger,

Were adorned with fine textiles,

Were adorned with gold and silver,

With golden portal, turquoise portal,

Silver portal, agate portal,

Copper portal, iron portal,

bSe stone portal,

With arrows, bows, and other weapons,

They were adorned.

The Bon was chanting and chanting,

The Counsellor (blon) was calculating and calculating,

On the nice copper pig,

All the ransom offerings were loaded, 
Consider the monkey - lhag se lhag!

The move of the fox - log gi log!

The voice of the badger - si li li!

The flight of the bird - lhab se lhab!

The voice of the pig - tse re re!

Those thirteen portals,

Are carried by the pig - lhang se lhang!

The portal of earth was purified by the pig.

By the monkey, the badger and the fox,

The great purification by burning ([sregs] sel chen po) was done,

By the smoke proceeding to the sky,

The window of the sky was purified,

The arrow-path of the Dü demons was cut off,

The flames of fire proceeded to the space in between,

[...] (and purified various beings including Nyen)

This rather confusing text appears to completely depart from the context promisingly indicated by the previous texts. However, in this case the text contains a rather mechanically repeated "series of mythical narrations" (rabs). It contains four more similar narrations, which repeat almost verbatim the phrases describing the problem to be solved and the ritual which follows then. Only the main characters are different. So, we meet here various ancestor figures: Muje Tsenpo (dMu rje btsan po), Royal son Thinge (written here as Rgya'u theng ghe = rGyal bu thing ge), Emperor-Lord of Tibet (Bod rje btsan po) and Tagcha Alol (sTag cha 'al 'ol). These figures belong to the same line as Yablha Daldrug (Yab lha bdal drug, among other spellings) in the non-Buddhist dynastic theogonies. Among the mythical priests Ya-ngal Gyimgong is also mentioned (Ya ngal Gyi gong gnyer = Ya ngal Gyim gong gnyer).

In general, the origin story is very different and in addition, the fox, the badger, a bird and the monkey are burned as well. There is insufficient space here to go into a detailed examination, but this context might be related to some surviving Bonpo funeral texts. And indeed, the absence of burial following the origin of the world is the primary cause of the intrusion of demons, in this case as well. In some texts used for the funeral ritual the "three blocker brothers" (thub chod spun gsum) are listed as the badger, the monkey and the bat (cf. Bellezza 2008, pp. 381-382, 390, 405). These three animals are used for blocking the demonic powers during the funeral ritual.

\section{The possible core of the tradition: the Nyen Collections (Gnyan 'bum)}

In this last section, where I will present the Tibetan texts available to me, the probable core of a tradition of the texts of Smoke Purification by Fox will be approached. All the Tibetan texts, with the sole exception of the last example introduced above, clearly describe the Smoke Purification by Fox ritual within the context of the worship of the Nyen beings. The most revealing and apparently oldest texts on Nyen are the so-called Nyen Collections (Gnyan 'bum). It is also in the Nyen Collections that the mythical priest Nyen Bon Thangthang Trolwa (gNyan bon Thang thang khrol/sgrol ba) frequently figures as a prominent ritual specialist dealing with Nyen.

There are three versions of various Nyen Collections available to me at the present time. One of them is included in the Bon Kanjur and represents a large corpus of texts comprising 165 folios $^{46}$. The second text appears in the New Collection of Bon Katen 
Texts. It is the shortest version, in 17 folios $^{47}$. The third text was photographed in Thewo in eastern Tibet and represents a version in 43 folios $^{48}$. All these three versions are apparently interrelated, and all of them contain a number of unusual words and unusual spellings.

Only the second of them can be dated (but one must, of course, be rather careful with the surviving reading - it could be well the subject of further amendments): its colophon mentions its discoverer Ponse Khyungotsal (dPon gsas Khyung rgod rtsal) who lived in the $13^{\text {th }}$ century in western Tibet. In addition, we have two accounts describing the two rediscoveries of the Nyen Collections as "treasure texts" (gter) appearing in the chronicles of the Bon tradition. The first account speaks about its discovery prior to 1017 in western Tibet. The second account does not give a precise date. It speaks about the master Kyangphag from eastern Tibet, who discovered the text in the Thewo region near Mount White Vulture Rock (Brag dkar bya rgod), and who flourished in the $11^{\text {th }}-12^{\text {th }}$ centuries (cf. Berounský 2013). The question as to whether the two undated and anonymous versions that are available can be related to these events narrated in Bon chronicles remains unknown. Despite the fact that the two versions are described as being having been rediscovered in western Tibet, I have argued elsewhere that their content points to the north-eastern Tibet as the place of their origin, and their lore is apparently associated with the mytho-poetical tradition of certain Nampa Dong (Nam pa lDong) clans and perhaps also Tanguts (cf. Berounský 2016, forthcoming).

of particular interest here is the fact that all these versions contain references to the ritual of the Smoke Purification by Fox. However, these references appear in different myths in each of the three versions, which, moreover, lack coherence and detail.

The first version of the Nyen Collection from the Bon Kanjur contains a mention of the Smoke Purification by Fox in the first text (called "chapter", le'u) entitled the Smoke Purification of the "Nol" Pollution of the Nyen (gNyan mnol bsang). The text is largely corrupt and certain sections of importance for proper understanding are obviously missing.

50 The text opens with the myth of the origin of eighteen beings; nine Ma (rMa) brothers and nine Numo $(\mathrm{Nu} \mathrm{mo})$ sisters. The second of the brothers is one of the main protagonists of the text: he is none other than Machen Pomra (sKu bla rMa chen pom ra), the famous mountain deity of eastern Tibet. He searches for his spouse and finds a beautiful lady called Lharimo (Lha ri mo). She hails from the family of beings called Gyake (rGya ske), who are also Nyen beings ${ }^{49}$. Then the text becomes abrupt; it states that Lharimo was polluted by murder $(s m e=d m e)$ and $m n o l$ (here probably indicating the pollution of fornication which is somehow related to nal, i.e. incest) without any detail. Indeed, the text then mentions the illegitimate child ( $m$ nol [evidently related to $\mathrm{nal}$, "incest"] gyi bu, "illegitimate child") Zardrag Tagtengmo (gZar brag stag steng mo). Machen Pomra becomes furious, kills the divine dzo (mdzo), which had been previously offered to him, and escapes. The relative brothers and sister are polluted (nal, "incest"), the local deities (yul sa) are polluted by quarrelling (gyod mkhon) and this causes the pollution (mnol) of the gods of sky. The entire land and serpent spirits $(k l u)$ are also polluted (mnol).

51 A ritual specialist named either Dabte Cagpo in the language of Nampa Dong, or Ya-ngal Gyimgong in Tibetan, appears on the scene ${ }^{50}$. He firstly cleanses the pollution with the aid of the blood (tshan) of birds. It is said that at the third month of each of the four 
seasons he purified the pollution by blood of three different birds ${ }^{51}$. Only then is the fox mentioned. The text says ${ }^{52}$ :

He caught a small fox of creation and ripped its back with a golden sword. Pure gods were cleansed. The enmity of brother and sister, Ma Shadra and Go Menri, the two, was purified. The purification of the pollution of fornication (mnol), murder and enmity (mkhon) originated thus. Kula Machen Pomra returned to his land. The text suddenly speaks about Ma Shadra (rMa sha bra), who is evidently one of the Ma brothers introduced at the beginning of the text (mentioned there as rMa'i sha sgra). Go Menri (sGo sman ri) might mean Lha ri mo, a lady chosen by Machen Pomra ${ }^{53}$. The mention of their names indicates that a substantial part of the story is missing in the text. We can connect the illegitimate child referred to in the text with this Ma brother, and his relationship with Lharimo, only hypothetically ${ }^{54}$.

There are two points to be stressed here. The Mongolian versions speak about a particular way of killing the fox. This should be done by a golden sword (or razor, pin, etc.). This element is present here as well. Despite the incoherencies of the myth, the fox is apparently used for purification of pollution caused by murder (dme), as well as incest or fornication ( $\mathrm{nal}$, sometimes mentioned as mnol). These two seem to represent the essential types of pollution of males and females respectively.

The second version of the Nyen Collection from Phenchu ('Phen chu) in eastern Tibet contains a separate section of the text entitled Smoke Purification by Fox (Wa bsang). But once again, the text is not very clear.

The myth opens with the creation of the gods, demons (srin), primordial man - the King Thangpo of Men (Mi rgyal Thang po), as well as various Nyen. Then creation becomes mixed up: the demons (srin) become attached to the people and Nyen, they even take several Nyen as wives. Demons dispatch an army in search of yet another Nyen wife. They arrive at the gate of the sky and the heart of the original lord of people, Thangpo, becomes sick. He addresses the heavenly priest (bon) and following his advice, he searches for powerful weapons which would be helpful against demons. The son of Thangpo, named Walpo Gudü (dBal po rGu 'dus), creates miraculous weapons and empowers them, besides other things, by drawing animals representing the Nyen of the various vertical layers of the world: dragon, lion, tiger, yak, etc. ${ }^{55}$ The weapons eventually cause the defeat of the demons and "their fort is destroyed and the tree of the demons is cut". In unclear passages, there is a mention of the pollution of beings including gods, Nyen and serpent spirits $(k l u)$, apparently due to murder and intermarriage among the primordial beings. The ritual of purification of the pollution as expounded by Shenrab Miwo is then dealt with. The text says: "The three birds of Nyen - the crane, the eagle (khyung), the grouse - and the fox and badger of creation were actually caught ${ }^{56}$ ". What follows is a myth on the origin of the four birds who serve as messengers to the Nyen; with their help, the Nyen should be purified. The text mentions the "purification blood" (tshan) of animals and then speaks about the fox rather inconsistently: "[...] the purification fox of creation was adorned with silks, and a silver bell was attached to its neck. The created world of the victorious Excellent Mountain was purified $[. . .]^{57 "}$ The text continues, making mention of cranes and other birds, including domestic fowl through which the Nyen of four cardinal directions and vertical layers of the world are purified. And then, only at the conclusion of this myth, is the fox mentioned again ${ }^{58}$ :

The remedying Nyen by the past King of humans Thangpo was good. The portal of the gods was opened and the portal of funerals was closed. The pollution of murder 
$(s m e=d m e)$ and of fornication ( $m n o l)$ were purified by means of the fox. The quarrels of the thousands of the created world were extinguished. The purification of the pollution of Nyen by fornication (mnol) was thus good. Now, it is the same for this patron of the ritual. This morning such clean [words of the ritual of] purification by means of the fox will be intoned to the retinue of serpent spirits, Nyen, lords of the

soil and Tö. May the pollution of fornication ( $m n o l)$ be purified by means of the fox! versions of the Nyen Collections a myth dealing with the Smoke Purification by Fox figures. Most of the previously introduced ritual texts obviously refer to the context of Nyen worship. It allows the possibility of considering the myths of the Nyen Collections as a principal tradition from which other separate texts probably stem. But the fox appears also in other contexts - as the ritual of the monkey, badger and fox might indicate.

\section{A note on pollution due to murder (dme) and to incest (nal)} these texts to represent the total number of the extant sources, and it is hoped ore of them will come to light in the future, thus shedding new light on the understanding of this interesting ritual. Despite the many problems with these texts, the only recourse is to rely on the available sources. The various Tibetan texts dealing with the enigmatic ritual of Smoke Purification by Fox
have been presented above to fill in some of the blank spaces on the map. One cannot the only recourse is to rely on the available sources. 

badger, fowl, monkey, goat and sheep, are listed as the subjects of purification rituals during which they are burnt. Yet it seems that the fox stands out in being treated as an exemplary animal, the sacrifice of which can purify the pollution of the murder of a relative (dme) and incest ( $\mathrm{nal}$ ). The use of the terms for incest (nal) and pollution nol (mnol, translated as "fornication" in this paper) - they appear to be connected - is quite puzzling and inconsistent. It could be understood as a term covering any number of kinds of pollution, but stemming originally from the word for "incest" (nal) and grammatically sharing the stem of the given word. This is expressed in one section in the Nyen Collection (the Kanjur version), where it is clearly stated that the deity was polluted (mnol) by "incest" (nal). Following this understanding, "incest" (nal) provokes a specific pollution of the deities $(\mathrm{mnol})$. It is possible that the meaning of nol ( $\mathrm{mnol}$ ) as a specific pollution by incest was only later extended to indicate pollution by any other form of sexual misconduct, and then eventually to all kinds of pollutions.

This, together with the pollution of murder of relative (dme), seems to be viewed as the principle pair of pollutions as related to males and females and the texts frequently mention the ritual to be particularly enacted for the pollution of murder ( $d m e)$ and the one related to improper sexual behaviour (whether mentioned as mnol or nal). Some other evidence linking these two pollutions might be seen in the oft-heard Tibetan proverb which mentions incest as "equal to murder ${ }^{60}$ ".

But in general, the situation is more complicated. While in some areas (including Thewo, Phenchu, and other areas of eastern Tibet from which most of the examples presented above come) the pollution designated nal (i.e. incest) is distinguished from the pollution dme (meaning "murder of relative" or "killing within one clan"), in another areas (notably western Tibet) the pollution dme is understood to stand for both "incest" and "murder of relative" at the same time ${ }^{61}$. It again shows that "murder of relative" and "incest" are seen as similar principle pollutions, which are crucial for the well-being of a clan. Sexual activity and killing are themselves good, but both have strictly prescribed social limits. Yet the terms applied for them might vary according to the area.

Most of the myths presented above view the ritual of burning a fox as an original ritual treatment for these pollutions, and the version of the Nyen Collection from Bon Kanjur even states so expressis verbis.

The connection of such pollution with the sexual misconduct of women seems to stand behind the rise of the widespread Buddhicized subgenre of "smoke purification rituals" entitled nol-sang (mnol bsang, "Smoke purification of nol pollution"), the same title as the text from the Nyen Collection of the Bon Kanjur version. There are number of these works, but a very frequently-used and well-known example is a text ascribed to Padmasambhava that features an interesting story about the origin of the ritual. In this scripture, entitled Blue Divine Water. The Smoke Purification of "Nol" Pollution ( $m$ Nol bsang lha chab sngon mo), an unfavourable state and sickness of the king Trisong Deutsen is described. It is stated that various epidemics, hail, famine and other natural disasters appeared along with his illness. Despite consultation with many astrologers and physicians, none of them could reveal the source of these afflictions. It transpired that the problems were due to his wife Mangza Tricham (Mang bza' khri lcam), who had given birth to a "polluted son" (mnol gyi bu). The text does not say more about him, but it is clear that he was, at the very least, an illegitimate child, if not a product of incest

Études mongoles et sibériennes, centrasiatiques et tibétaines, 50 | 2019 
(nal gyi bu). This son was hidden in a cave by the queen's maidservant. There, according to the text the child "touched the belly of the lord of the soil and polluted all the lords of the soil and territorial gods ${ }^{62}$. Of course, this was then discovered by Padmasambhava, who presented the smoke purification ritual (bsang), thus purifying the pollution.

It is very striking that this - perhaps the most renowned - Buddhist nol-sang (mnol bsang) text views the principal pollution to be that of sexual misconduct of a woman. This is very much in line with the texts on the Smoke Purification by Fox and thus the question naturally arises as to whether this represents the Buddhist reworking of the ritual.

\section{Concluding remarks}

The role of the fox remains rather puzzling. The Nyen Collections - probably representing the textual context of the ritual - do not provide a single clue as to why precisely the fox should be burnt. But the other texts indicate that the fox originated from an incestuous relationship in which the heavenly forefather of earthly beings Yabla Dedrug engaged. Some of the texts do not necessarily indicate incest as such; a polluting intercourse with demonic figures might play a role as well - as is the case of the third Tibetan text on burning the monkey, badger and fox. Only the second text presented above rather surprisingly narrates the consumption of the "ambrosia" of Yabla Dedrug by the fox, which explains its purifying qualities. Nevertheless, even without such a mention, the ambiguity of the fox is clear enough from its origin in the pure heavenly being Yabla Dedrug, yet through a polluting incestuous relationship.

67 At the present state of knowledge one can tentatively see the core of the tradition to be associated with the Nyen Collections. But its existing versions have different wordings and are missing any myth explaining why namely foxes should be burnt. Such mythical explanation is present in other texts including those translated into Mongolian. These, however, have already entered different ritual traditions, about which we know very little in terms of their origins and evolution. One can, nevertheless, observe a rather fluid environment, in which it would not be safe to postulate some single original text.

68 Left with these various narrations on the fox, one cannot ignore the widespread tradition in China, Korea and Japan, where foxes are beautiful ladies who seduce males. This could be hypothetically linked to the fox as an animal that purifies either "incest" in the narrow sense, or "fornication" in the broader one.

But there is also another possible connection that is worth mentioning: the old Persian tradition represented by the so-called Greater Bundahishn, where each of the original human sibling pair is married to a demonic dev. The "tailed being" coud be a reference to the fox (Anklesaria 1956, p. 91):

This, too, one says, "Jam, when [his] light had departed from him, took a she-dev to wife, and gave his sister Jami to a dev to wife, owing to the fear [of] the devs; the ape, the bear, [the resident of the forest] the tailed being, and other noxious races arose from them; [his] lineage did not progress therefrom [...]"

70 This could be related to the tradition of burning the fox, badger and monkey represented by one of the texts above ${ }^{63}$. While most of the texts presented above speak about incestuous relationship, this particular case mentiones improper sexual relationship enacted in order to avoid incest. This improper intercourse between 
original/pure beings and demons gives rise to animals representing such polluting intercourse (which could be seen as an extention of incest). Here we may recall the famous Buddhist myth of the origin of Tibetans from the relationship between Avalokiteśvara and a demoness, giving rise to ancestral Tibetans who were originally born as monkeys. This myth employs the same motif of union between pure and demonic beings resulting in the origin of monkeys in this case. This idea is not very far from what appears in another Tibetan text on the origin of Tibetans entitled The Appearance of the Little Black-headed Man, which was dealt with by Samten G. Karmay (Karmay 1986, 1998). This time the demonic devs appear to be Nyen (gnyan) (Karmay 1998b, p. 267):

['Ting ge] [...] married a Nyen woman and they had four sons: the monkey, the badger, the brown bear (the fourth is missing). They are non-human, but similar to $\operatorname{man}[\ldots]$

Figure 4. Places of occurrence of the fox-fumigation texts

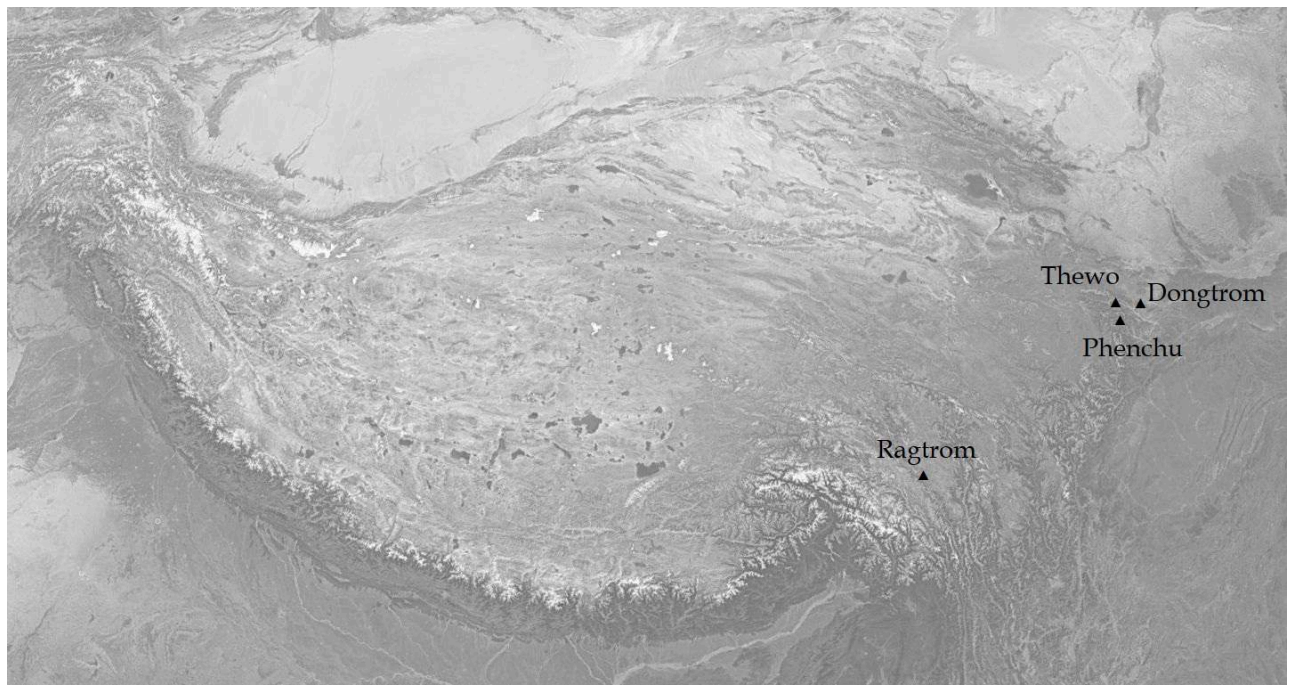

(c) Daniel Berounský

As for localizing the tradition, most of the texts presented above point unequivocally to north-eastern Tibet as their place of origin. The scenario proposed here is that the ritual is strongly associated with the Nyen Collections, which for the most part represent the lore of the Dong clan and particularly the tradition of Nampa Dong (Nam pa lDong). The location of ancient Nampa Dong cannot be specified precisely, but it should be somewhere in the vicinity of Mt. Machen Pomra in eastern Tibet (cf. Berounský 2017). Besides several texts containing names both in the language of Nampa Dong and Tibetan, there is also a single text of the Nyen Collection (Bon Kanjur version) containing both Tangut and Tibetan names. This could indicate the proximity of this particular Dong clan to the Tanguts (cf. Berounský, forthcoming). The appearance of the ritual texts presented above in the areas of Phenchu and Dongtrom could well represent some remnants of the lore of Nampa Dong. The version ascribed to Sherab Gyaltshen attempts to enter the domain of monastic Bon, while the version from Ragtrom in Kham might witness the migration of the Dong clan.

Rather surprisingly, this lore made its way to Mongolia. The Mongolian versions and their number attest to the widespread distribution of this Tibetan Bon ritual throughout Mongolia. They provide fair evidence of the influence of the Tibetan Bon 
tradition (with all the variety of meanings covered by this vague term) in Mongolia. The confusion concerning the identity of the main characters of the myth (Yabla Daldrug and the Nyen) in Mongolian versions makes it clear that these texts were translated from Tibetan, and do not stem from some other hypothetical Central Asian source.

Figure 5. Stuffed fox inside the "fumigation altar" (bsang khri) near Bardan monastery in Zanskar

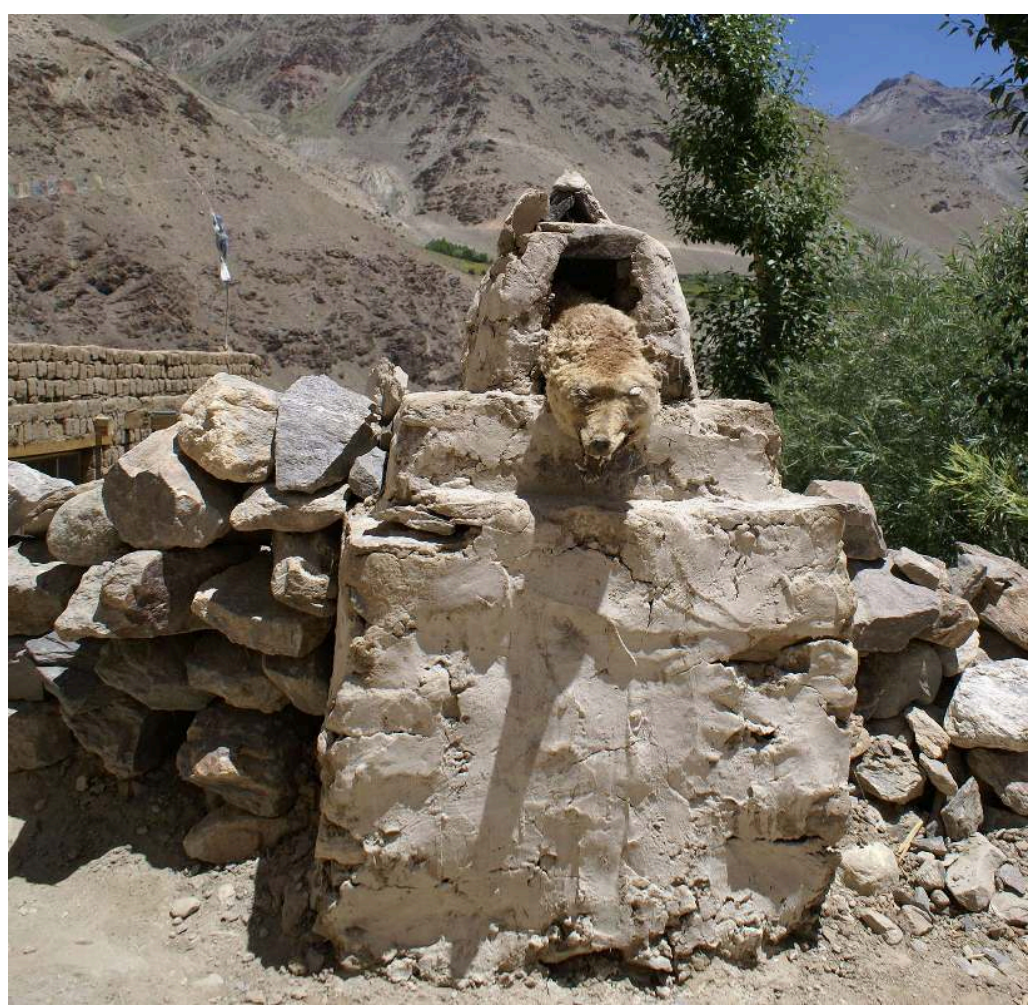

(c) Martin Hribek, 2009

The presence of the existence of a similar tradition in western Tibet is not attested by any text known so far, but is suggested by the photograph of the stuffed fox in the "fumigation altar" (bsang khri) taken in Zangskar (Zangs dkar, see the Plate). Besides the rediscovery of the Nyen Collection in western Tibet (probably due to migration), this is the single known indication of the presence of this ritual in any western part of ethnographic Tibet.

BIBLIOGRAPHY 


\section{Tibetan primary sources}

Bon+'di nas reng wa yes dbus l+ya+s+ho [The long-nosed fox of this Bon], in 'Brug thar (ed.), $2011 \mathrm{mDo}$ smad mDa' tshang yul gyi gna' dpe phyogs bsdus mthong ba don ldan, vol. 26 (Gansu wen hua chu ban she, Lanzhou), pp. 1-8.

gSang grags wa bsang khu byug gdang(s) skad [Secret of the smoke purification by [means of the] fox [called] the voice of the cuckoo], New Collection of Bonpo Katen Texts (see Karmay \& Nagano 2001, vol. 122, text no. 40, pp. 319-323).

Khyung gser zhun 2014 Go lde 'phags pa'i rnam thar yul mi'i ngag sgros [Hagiography of Gode Phagpa according to the accounts of local people] [online, URL: http://blog.himalayabon.com/u/ bonnaktwang/archives/2014/3607.html, accessed in November 2017].

mDo dri med gzi brjid [Sutra of stainless Splendour], vol. 2, Pa sangs tshe ring (ed.) 2000 (Bod ljongs bod yig dpe snying dpe skrun khang, Lhasa).

mNol bsang lha chab sngon po [Blue divine water. The smoke purification of "Nol" pollution], in 1993 bSang mchod bkra shis 'khyil ba (mTsho sngon mi rigs dpe skrun khang, Xining), pp. 123-145.

Na ris wa ba'i dbu lags tho [The long-nosed fox], in 'Brug thar (ed.), 2011 mDo smad mDa' tshang yul gyi gna' dpe phyogs bsdus mthong ba don ldan, vol. 24 (Gansu wen hua chu ban she, Lanzhou), pp. 286-294.

Na ris wa yin dbul+s+ho [The long-nosed fox], in 'Brug thar (ed.), $2011 \mathrm{mDo}$ smad mDa' tshang yul gyi gna' dpe phyogs bsdus mthong ba don ldan, vol. 10 (Gansu wen hua chu ban she, Lanzhou), pp. 9-17.

'No'di nas na res wa yes dbu lagstho [The long-nosed fox of this Bon], in 'Brug thar (ed.), mDo smad $m D a$ ' tshang yul gyi gna' dpe phyogs bsdus mthong ba don ldan, vol. 2 (Gansu wen hua chu ban she, Lanzhou), pp. 6-12.

Nye lam sde bzhi'i gnyan 'bum bzhugs pa'i dbus phyogs legs swo [The Nyen collection of the fourfold direct path], New Collection of Bonpo Katen Texts (see Karmay \& Nagano 2001, vol. 253, text no. 25, pp. 603-635).

'Phen yul rgyas pa gnyan gyi 'bum bshugs stho [The Nyen collection of the extensive Phenyul], 43 folios, manuscript photographed in Thewo (eastern Tibet) by Ngawang Gyatso.

rNam par dag pa'i 'bum bzhi las rin po che gnyan gyi 'bum bzhugs so [The Nyen collection from the Completely Pure Fourfold Collection] (NB), Bon Kanjur, vol. 78, 165 folios.

sTong gsum 'khrug pa yo bcos kyi wa bsang sngon mo bzhugstho [Blue smoke purification by fox [from the ritual cycle of] bringing all disturbances of the triple thousand world to harmony], New Collection of Bonpo Katen Texts (see Karmay \& Nagano 2001, vol. 84, pp. 95-102).

Wa 'i dbu lhags tho [The fox] in 'Brug thar (ed.), mDo smad mDa' tshang yul gyi gna' dpe phyogs bsdus mthong ba don ldan, vol. 22 (Gansu wen hua chu ban she, Lanzhou), pp. 7-10.

Wa sprel grum gsum dbu lags tho [The fox, the monkey, and the badger: the three), incomplete anonymous manuscript photographed by Ngawang Gyatso in Thewo.

Zhabs dkar tshogs drug rang grol 2002 Rje zhabs dkar tshogs drug rang grol gyi gsung 'bum [Collected works of Zhabkar Tshogdrug Rangdrol], vol. 7 (Xining, Mtsho sngon mi rigs dpe skrun khang). 


\section{Secondary sources}

Anklesaria, B. T. (transl., ed.) 1956 Zand Akasih. Iranian or Greater Bundahishn (Bombay, published for the Rahnumae Mazdayasnan Sabha by its Honorary Secretary Dastur Framroze A. Bode).

Bawden, C. 1976 The "offering of the fox" again, Zentralasiatische Studien 10, pp. 439-473. 1978 An Oirat manuscript of the "offering of the fox", Zentralasiatische Studien 12, pp. 7-34.

Beckwith, C. I. 2011 On Zhangzhung and Bon, in H. Blezer (ed.), Emerging Bon. The Formation of Bon Traditions in Tibet at the Turn of the First Millenium AD (Andiast, International Institute for Tibetan and Buddhist Studies), pp. 164-184.

Beffa, M.-L. \& R. Hamayon (eds) 1984a Le renard : tours, détours \& retours, Études mongoles et sibériennes 15.

$1984 \mathrm{~b}$ Qui confond pur et impur purifie par le renard, in Le renard : tours, détours \& retours, Études mongoles et sibériennes 15, pp. 141-151.

Bellezza, J. V. 2008 Zhang Zhung. Foundations of Civilization in Tibet (Vienna, Verlag der Österreichischen Akademie der Wissenschaften).

Berounský, D. 2013 Bon religion in $11^{\text {th }}-12^{\text {th }}$ century Amdo. A case of Kyangphag Mula Drungmu (sKyang 'phags mu la drung mu), Asiatische Studien/Études Asiatiques 67(3), pp. 783-808.

2017 The Nyen Collection (Gnyan 'bum) and Shenrab Miwo of Nam, in J. Ptáčková \& A. Zenz (eds), Mapping Amdo (Prague, Oriental Institute, Archiv Orientalni, Supplementa X), pp. 211-253. forthcoming, Old Tibetan myth on retribution for killing the Nyen (gnyan stong). Manuscripts scattered between Naxi, Tanguts, Eastern and Western Tibet, A. Hellman-Waźny \& C. Ramble, Charles (eds), Bon Manuscript Culture (Boston/Berlin, DeGruyter, Studies in Manuscript Cultures series).

Blezer, H. 2008 sTon pa gShen rab: six marriages and many more funerals, Revue d'Etudes Tibétaines 15, pp. 412-479.

2011 In search of the heartland of Bon - Khyung lung Dngul mkhar the silver castle in Garuda Valley, in H. Blezer (ed.), Emerging Bon. The Formation of Bon Traditions in Tibet at the Turn of the First Millenium $A D$ (Andiast, International Institute for Tibetan and Buddhist Studies), pp. 117-163.

Buffetrille, K. 1998 Pèlerinage et inceste. Le cas de mChod rten nyi ma, in A. M. Blondeau (ed.), Tibetan Mountain Deities. Their Cults and Representations (Wien, VÖAW), pp. 19-39.

2004 Pilgrimage and incest. The case of Mchod rten nyi ma, Bulletin of Tibetology 40(1), pp. 5-38. 2016 "Beasts, Men and Gods". A Dmar bsang ritual in Khri ka (Amdo), paper given at the XIV $^{\text {th }}$ Seminar IATS, Bergen, June 22, 2016.

(this volume) "Beasts, Men and Gods". A red purifying smoke offering (marsang) in Trika (Amdo) (wa bsang), Études mongoles \& sibériennes, centrasiatiques \& tibétaines 50 [online, URL: https:// journals.openedition.org/emscat/3893, accessed 4 March 2019].

Childs, G. 2006 Namas (mna' ma) and Nyelus (nyal bu). Marriage, fertility and illegitimacy in Tibetan societies, in C. Klieger (ed.), Tibetan Borderlands (Leiden, Brill), pp. 89-113.

Coloo, J. 2001 Incense offering of the fox in Oirat script, in H. Walravens (ed.), Der Fuchs in Kultur, Religion und Folklore Zentral- und Ostasiens (Wiesbaden, Harassowitz Verlag), pp. 59-73.

Diemberger, H. \& G. Hazod 1997 Animal sacrifices and mountain deities in Southern Tibet. Mythology, rituals and politics, in S. Karmay \& P. Sagant (eds), Les habitants du toit du monde. Volume in Honour of Alexander Macdonald (Paris/Nanterre, Société d'ethnologie), pp. 261-281.

Heissig, W. 1976 Zur Morfologie der “Fuchsopfer”-Gebete, Zentralasiatische Studien 10, pp. 475-519. 
Huber, T. 2013 The iconography of gShen priests in the ethnographic context of the extended Eastern Himalayas, and reflections on the development of Bon religion, in F.-K. Ehrhard \& P. Maurer (eds), Nepalica-Tibetica. Festgabe for Christoph Cüppers, vol. 1 (Andiast, International Institute for Tibetan and Buddhist Studies), pp. 263-294.

Karmay, S. G. 1972 The Treasury of Good Sayings. A History of Bon (Oxford/London, University Press). 1995 Les dieux des terroirs et les genévriers. Un rituel tibétain de purification, Journal Asiatique 283(1), pp. 162-207.

1998a The local deities and the juniper tree. A ritual for purification (bsang), in S. G. Karmay, The Arrow and the Spindle. Studies in History, Myths, Rituals and Beliefs in Tibet (Kathmandu, Mandala Book Point), pp. 380-412.

1998b The appearance of the little black-headed man, in S. G. Karmay, The Arrow and the Spindle. Studies in History, Myths, Rituals and Beliefs in Tibet (Kathmandu, Mandala Book Point), pp. 245-281 (original French version was published in Journal Asiatique 274(1-2), Paris 1986, pp. 79-138). 2010 Tibetan indigenous myths and rituals with reference to the Ancient Bön text: The Nyenbum (Gnyan 'bum), in J. I. Cabezón (ed.), Tibetan Ritual (Oxford, Oxford University Press), pp. 53-68.

Karmay, S. G. \& Y. Nagano (eds) 2001 A Catalogue of the New Collection of Bonpo Katen Texts (Osaka, National Museum of Ethnology, Bon Studies 4).

Martin, D., P. Kværne \&Y. Nagano (eds) 2003 A Catalogue of the Bon Kanjur (Osaka, National Museum of Ethnology, Bon Studies 8).

Nagano, S. 2000 Sacrifice and lha pa in the glu rol festival of Reb-skong, in S. G. Karmay \& Y. Nagano (eds), New Horizons in Bon Studies (Osaka, National Museum of Ethnology, Bon studies 2), pp. 567-649.

Nebesky-Wojkowitz, R. de [1956] 1993 Oracles and Demons of Tibet. The Cult and Iconography of the Tibetan Protective Deities (Kathmandu-Varanasi, Book Faith India).

Ngawang Gyatso 2016a A comparison and preliminary study of leu manuscripts from Phan-chu, The-bo and lDom-khrom, transl. by C. Ramble, paper given at the workshop Bonpo Manuscript Culture: Towards a Definition of an Emerging Field, The Centre for the Study of Manuscript Culture, University of Hamburg, 11-12 March 2016.

2016b The Lhadag leu (lha bdag le'u), ritual specialists of the black water Bon of the phenomenal word of Amdo, Archiv Orientální 84(3), pp. 561-575.

Ramble, C. 1998 The classification of territorial divinities in Pagan and Buddhist rituals of South Mustang, in A.-M. Blondeau (ed.), Tibetan Mountain Deities, their Cults and Representations (Wien, Verlag der österreichischen Akademie der Wissenschaften), pp. 123-143.

2008 The Navel of the Demoness. Tibetan Buddhism and Civil Religion in Highland Nepal (Oxford, Oxford University Press).

2014 Real and Imaginary Tibetan Chimeras and their Special Powers, Mongolo-Tibetica Pragensia '14 7(2), special issue, Indigenous Elements in Tibetan Religions, pp. 13-33.

Rdor phrug, Mgon po dbang rgyal, Skal bzang don grub \& Chos 'dzin 2009 Krung go'i bod brgyud nang dgon dkar chag las kan su'u glegs bam (Lanzhou, Kan su'u mi rigs dpe skrun khang).

Rnam rgyal tshe ring 2001 Bod yig brda rnying tshig mdzod (Beijing, Krung go rig pa dpe skrun khang).

Sárközi, A. \& A. G. Sazykin 2001 An incense offering of the fox, in H. Walravens (ed.), Der Fuchs in Kultur, Religion und Folklore Zentral- und Ostasiens (Wiesbaden, Harassowitz Verlag), pp. 75-148.

Serruys, H. 1970 Offering of the fox. A shamanist text from Ordos, Zentralasiatische studien 4, pp. 311-325. 
Snellgrove, D. 1967 The Nine Ways of Bon (Oxford, Oxford University Press).

Tsering Bum 2013 A northeastern Tibetan childhood, Asian Highland Perspectives 27.

\section{NOTES}

1. The research on this article was supported by the Grant Agency of the Czech Republic (GACR), project no. 17-01246S, "Nyen Collection (gNyan 'bum) in the Old Tibetan Literary and Ritual Tradition". I would like to express my heartfelt thanks to Ngawang Gyatso, who generously provided me with a number of the texts presented here as well as with very useful comments. I am also indebted to Charles Ramble for his very useful suggestions and improving English of this text.

2. This information was provided in personal discussion by Ngawang Gyatso, a lecturer from Lanzhou University, who is a native of Thewo and has researched the le'u tradition there (July 2016). For an introduction to the ritual tradition called le'u see Ngawang Gyatso 2017. He mentioned that nowadays a few hairs from the traditional fox fur hat are simply plucked and thrown onto the burning sang.

3. According to Ngawang Gyatso, Datshang is a reconstructed name from Chinese. The proper Tibetan name of the locality is Dongtrom (lDong khrom). Personal communication, July 2017.

4. My translation. For another translation, see Snellgrove 1967, pp.46-49; for the published version of the Tibetan original see mDo dri med gZi brjid, vol 2, pp.416-417. Karmay refers to a place in the gZi brjid where the same list of pollutions appears and then to yet another text (Karmay 1995, 1998). This suggests that such a list of pollutions was somehow standardised. The Tibetan text reads: [...] gtsang sme blang dor ma phyed pas// mi dge nyes pa'i gzhi ma byung// dme dang mug dang nal dang btsog// than dang ltas ngan byur yug 'bag// thab dang mkhon dang dbar la sogs// de dag lha yi spyan la phog// gtsang ris lha la mnol phog pas// gzhi gnas mnga' dbang yul sa mnol/ de yi grib chags kha rlangs rnams// 'gro ba mi yi tshogs la phog// 'jig rten zhing 'dir dbul 'phongs dang// nad dang mu ge 'khrugs pa dang// mi bde sdug bsngal sna tshogs 'byung// de dag bsang zhing dag pa dang// 'gro ba ma lus gso ba'i phyir// chab nag srid pa rgyud khog la/ sel sgo shing lo 'dab rgyas byung// dkar nag bsal bas sel zhes bya//[...].

5. For example, several cases of animal sacrifices practised in southern Tibet are described by Hildegard Diemberger and Guntram Hazod (Diemberger \& Hazod 1997), while another interesting case is mentioned by Charles Ramble in his book dealing with village of Te in Nepal (Ramble 2008, pp. 195-202).

6. Katia Buffetrille gave her paper “'Beasts, Men and Gods'. A dMar bsang ritual in Khri ka (Amdo)" at the Fourteenth Seminar of the IATS in Bergen. The offering of a goat was presented to the interesting deity Khri ka'i yul lha as a part of sang ritual, and part of the body of the goat was burnt during it (Buffetrille 2016). See also her contribution to this volume.

7. The reference from Lurol mentions the burning of part of the body of the animal, while other parts of the animal are boiled and consumed by people (cf. Nagano 2000, pp. 576, 595).

8. A short description of burning five roosters (apparently as a dmar bsang ritual) in the village temple prior to the archery contest with the neighbouring village appears in Tsering Bum's popular writing about his childhood (Tsering Bum 2013, p. 88) from Kewa (sKe ba) village of Mangchu (Mang chu) township of Amdo. The roosters were killed by cutting their throats; they were then put into the fire and sprinkled with their blood, which had been collected when they were killed.

9. For example, it is mentioned twice in the book dealing with the Buddhist monasteries of Kansu province (see rDor phrug et al. 2009, pp. 104, 683). 
10. The locality is not mentioned in the text, but Zhabkar hailed from Rebkong (Reb gong). It is thus quite probable that he describes practices prevalent in this area. The Tibetan text reads: yang na gson por khog gi snying dmar tsa re blangs lag na 'gul bzhin bsang gi nang du bzhag nas dmar bsang gtong ba dang/sha khrag gis mchod pa dang/[...].

11. This is taken as a simple fact here. It certainly might point to the geographical distribution of such rituals, but one must be cautious, since it can be due simply to a lack of references from other Tibetan areas. I have been informed by Toni Huber (personal communication, June 2017) that body parts of animals are often burnt in the areas of Arunachal Pradesh and eastern Bhutan. More information will be available in his upcoming monograph.

12. Sárközi and Sazykin cite other publications in Mongolian, which are omitted here.

13. Called Gülmü, Nilmu and Salmu (version 3) or Kolmo, Gyulmo and Sgelmo (version 8) or Gülemü, Ilamu and Salamu (version 9). The Tibetan female particle mo is apparent in their names and thus one can conclude that they are Tibetan names phonetically rendered in Mongolian.

14. Vege, Muge, Qanay, Munay, Gasu, Musu, Gabri, Mubri and their sister Müriyen (version 3); Yeke, Moga, Kasu, Mosu, Kanak, Munak, Karca, Marik and mother of the fox (version 8); Vaga, Môga, Kasu, Mosu, Ganag, Munag, Gabari, Mubari and sister Marayan (version 9). Though the Tibetan originals of the names are hardly reconstructable, an exception may be the pair named Kanak and Munak. These are (in their variety of Mongolian spellings) probably dKar nag and Mun nag in Tibetan (i.e. White-black and Dark-black).

15. According to the version 3 . Version 8 gives names Ridu and Ridu (sic!), saying that they became rabid; version 9 speaks about Ker-tu and Nirvang who become stupid.

16. The version 9 speaks about Faith King, for the Determiner-King (version 8: Zayaači khan, version 3: Jayayan). But this name also appears in the third redaction in various spelling.

17. This also concerns version 3 of the previous redaction. Version 8 does not contain the beginning of the text, while version 9 has simply "Jee" (Tib. kyai). The first redaction (versions 1 and 2) pays homage to Göngdzii Khan (Tib. Kong tse rgyal po).

18. Tib. ma sang: rather enigmatic demonic beings figuring both in Mongolian and Tibetan folk traditions (cf. Nebesky-Wojkowitz 1993, pp. 221, 224-25).

19. This hypothesis is supported by the sudden appearance of Seven Fierce Stars and the figure of Mañjuśrī. The Seven Fierce Stars can be identified with the constellation of the Plough, which is, however, more commonly known as simply "Seven Stars" (Mo. doloyan odun) or "Seven Old Men" (Mo. doloyan ebügen) in Mongolian. Nevertheless, contrary to the case of Tibet, the cult of the Plough was widespread in Mongolia (and also China). The buddhisized form of this cult represents an apocryphal scripture, the so-called Plough Sūtra, in which Mañjuśrī introduces each of the Seven Stars as protectors. Although this text was translated into Tibetan from Mongolian and appears in the Peking editions of Kanjur, it has never received widespread attention in Tibet. As will be apparent, the "Seven brothers of Nyen beings" appear in the Tibetan versions. Nyen are not known to Mongols and their name was translated as "fierce", which is one of the possible meanings of the expression in Tibetan.

20. As a mythological figure, he is mentioned in the $m D o$ 'dus (probably $11^{\text {th }}$ century), where he is introduced as a father-in-law of the mythical founding figure of Bon, gShen rab mi bo. In the later text gZer mig, he is depicted as a disciple of gShen rab mi bo, building a palace of Bon teachings in a ocean. In a discussion of an episode from this scripture, a dialogue between Kongtse and Miraculous Boy, Samten G. Karmay pointed out the similarity of this narration to the well-known stories about Confucius in China. It seems thus that his appearance in the Bonpo sources was loosely inspired by Confucius, but he attained the specific role of a master of astrology. Indeed, he is named as the author of a number of Bonpo texts, namely rituals associated with astrology. But another story about him also appears in the "Buddhist" compendium on astrology Bai dūrya dkar po (The White Beryl) composed by the regent of the fifth 
Dalai Lama Desi Sangye Gyatso (sDe srid Sangs rgyas rgya mtsho, 1653-1705) and he is also named as the author of rituals within the "Buddhist" traditions, mainly of the rNying ma pa.

21. Mo. zuryan züyiliyin ecege eke (Sazykin \& Sárközi, p. 118), see also Bawden 1976, p. 445.

22. This name appears as early as in Dunhuang documents (Yab bla bdag drug, PT. 1286, ITJ 731) and in the Kongpo inscription dated to $9^{\text {th }}$ century CE.

23. Although the title of the publication mentions Datshang ( $\mathrm{mDa}$ ' tshang), the Tibetan name of the locality is lDong khrom. See note 3.

24. Ngawang Gyatso and Sherab Dragpa (a le'u ritualist who still performs the ritual himself), personal communication (July 2017).

25. Most of the versions mention seven of them, but one version has nine foxes. The names of these two extra foxes are given in the square brackets below.

26. A specific sign standing for number 7 .

27. Tib. gSang grags wa bsang khu byug gdang(s) skad, Katen 122-40 (fols 319-323). The so-called New Collection of Katen Texts is a vast corpus of surviving texts of Bon published by Sog sde bsTan pa'i nyi ma and catalogued in a publication edited by Samten G. Karmay and Yasuhiko Nagano (Karmay \& Nagano 2001).

28. Katen 122-40, fol. 319: nga ni kun tu bzang po ste/ nga la nga med kun tu bzang/ kun tu bzang po rtsi yi khung/ kun tu bzang po dug gi khung/ kun tu bzang po kun gyi gzhi/ kun gzhi rnam dag sgrib pa med/.

29. Katen 122-40, fol. 320-321: kyai de ring srid pa'i khri gdug la/ srid pa gnyan la bsang 'debs so/ mkha' la khri gdug shar tsam na/ mi gsal shes rmug 'thib gnas med/ srid pa'i wa bsang sel btab pas/ rme mnol mi gtsang chags gnas med/ rme mnol thams cad dag gyur cig// gnas sngon srid pa'i dang po la/gnyan yul pho mo gser steng na/ gnyan bon thang thang khrol ba bzhugs/ sems can don la brtse dgongs nas/ bon gyi bstan pa dar ba'i phyir/ bdud srin ma rung 'dul slad du/ srid pa'i gnyan khams dar la mi khams rgyas/ sngon gyis srid pa'i bzang shul du/ srid pa gnyan la wa bsang 'debs/ srid pa gnyan la tshan khrus gsol/ lha khams thams cad dag gyur cig/ gnyan khams thams cad tshangs gyur cig/ mi khams thams cad dag gyur cig/.

30. Tib. dme mnol dag pa'i bsang khrus gyi cho rab(s) 'di/ gshen gyi drang srong shes rab rgyal mtshan gyis sman ri'i khrod du sbyar ba'o.

31. See Go lde 'phags pa'i rnam thar yul mi'i ngag sgros by Khyung gser zhun. The rock is known as Rag khrom brag, currently better known as Rag kram brag according to the text.

32. For example, both the corpora of texts contain a narrative about the origin of the bat. Cf. Ramble 2014.

33. This part is apparently corrupt and unfortunately there is no clue as to how it should be amended. The Tibetan text reads (p. 95): kya'i wa 'di yi cho chen 'brang ring ba'i/ wa 'di'i pha ni gnam byi de ni dun dun dang/ ma ni sa la zhal zhal nas/ de gnyis len gcig bshos pa la/ bsang gi wa ni gsum du 'byung/.

34. Tib. 'di ni bsang gi wa lcang lcang [...] This expression lcang seems to be related to the lcang rnyid meaning strong desire.

35. The Tibetan text reads: sngon sa bdag klu gnyan wa'i bsang ba gar srid na/ sngon gyi gnam gyi ya bla na/ phya rje bla bde drug de/ bdud rtsi bdag po gnas pa yin/ de kyang bdu+id'i (bdud rtsi'i) thang ma bdal/ sa la m+to+e+g (me tog) 'khrung pa'i bdu+id (bdud rtsi) thang ma chos (='chos)/ bdud rtsi dang ma sa la bab pa la/ sa la bdu+id'i (bdud rtsi'i) me tog 'khrung/bdu+id (bdud rtsi'i) me tog des/ rdzu 'phrul 'bung pa'i tshang su song/ bdu+id (bdud rtsi'i) 'bung pa'i tshang nang ni/ wa mo mun la song ba mthong/ bdud rtsi 'bung tshang wa yi zos pa la/ wa'i bdu+id (bdud rtsi) zos pa'i yon tan gyis/ spu la me+o+tog (me tog) bkra pa dang/so la me+o+tog (me tog) bkra ba dang/ [...] (incomprehensible part)/ de bas wa la bdu+id (bdud rtsi) yod/ des sa bdag klu gnyan tham+d (tham cad) mi bde ba bsang/ is bag klu (that bsangt wa'i sha rnams (rnams) bsregs pa'i/ dud pa gnam du song pa'i gnams (=gnam) kyi gnyan rnams thams $+d$ (thams cad) bsang/ me lce bar du song ba'i/ bar snang gnyan rnams (rnams) bsang/ 'dab ma sa la song ba'i/ sa la gnyan pa'i (=gnas pa'i) sa bdag klu gnyan bsang/. 
36. Thang ma=bkram pa (bTsan lha, rNam rgyal tshe ring), but later in the text this is written as dang ma. There is a probablility that it means dwang ma - "essence", "refined", "pure", etc.

37. Chos ='chos (prepare, make ready, etc.)

38. 'Bung $p a=$ bung $p a$.

39. The three verses are added as glosses; the third one is partly illegible.

40. Tib. 'dab ma. It is not clear what is meant by this expression. From the context, it could be interpreted as a burnt fox falling apart. But this expression commonly means "petal leaves" of a flower. Since the flower is in possession of the fox, this could be a plausible interpretation.

41. The Tibetan text reads (p. 99): skabs 'dir wa sha dum cig dang drud shing gnyis mar la bod pa (=bor la) 'di skad do/ kye'e wa 'di gtan du mi bsreg go/ wa 'di gtan du bsregs pa na/ rtsogs dgu dman na sha wa'i zos/ mi ro ni wa'i drud/ rta ro ni wa'i bshad (=gshed?)/ de ba'i wa'i gtan du mi bsong (=bsreg) go/ wa'i mkhal ma thur du bor/ rtsogs gi mkhal mo ma thur du bor/ nal gyi mkha' ma (=mkhal ma) mthul (=thur) du thor/dme'i mkhal ma mthur (=thur) du bor/ mug+i (mug gi) mkhal ma thul du bol (=thur du bor)/ pho shi dri'i mkhal ma mthur (=thur) du bor/ mo shi dri mo'i mkhal ma thur du bor/ [...].

42. The Tibetan text reads: kye'i dang po ye med stong pa las/ de las ye yod cung tsam srid/ de las srid pa'i rlung du srid/ rlung kor (dkar po) las dung mi las-srid/ rlung sngon+o (sngon po) las smon mi dbu nag srid/ rlung nog (nag po) las ngam mi nor (=nag po) srid/ rlung dmor (dmar po) las zang (=zangs) lcag (=lcags) rgan rgon srid/ rlung nog'i (nag po'i) ser+o (ser bas?) bsad/ shi ba sus ma 'dur/ nog (nag po) dme 'dre dang/ ser+o (ser ba'i) bser r+gis (bse rag gis)/ dung myi lhad kar (dkar) la/ nyo+ya (nyon rmong?) gtong zhing bgag sgo 'gyer (?' 'gyed)/ mtsher brtsub (=rtsub) chen+o (chen po) lang/ mas gyis sa sgo phye/ ya bdud kar (gangs) ltar rnyil ma khar (khad)/[ma bdud chu ltar khol/] par (=bar) btsan rlung ltar 'tshubs ma khod (=khad)/ bdud btsan skel (=rgal) sgo bye/ gnam la bya skad ngan/ [sa la byi skad ngan/] brag la wug pa ('ug pa) rgod/ [...].

43. These phrases are repeating later in the text (p. 8) and this one is apparently missing in the text.

44. Again, these phrases are repeated later in the text and this one is missing here.

45. The Tibetan text reads (p. 2): de dung bon s+yer dbu ny+y+er (dung bon ser bu gnyer?)/ dung brag kor (dkar po) la/ dung gis 4 ma (gzhi ma) ting (=bting)/ g.yu'i snab na blugs/ s+y+er (=gser) rdo mthu+en ( $m$ thu chen) btsugs/ dung spril (=sprel) dkor (=dkar po) la/ g.yu'i rnyig ma (=smin ma) can/ dung gis bya po la/ g.yu'i gshogs pa can/ dung gi grum pa la/ g.yu'i snyig ma (=smin ma) can/ dung gi wa 'o (=wa mo) la/ g.yu'i mchu sder+n (=sder can)/ de rnams s+yer (gser) dngul dung mchong chasu (chas su) bcug/la la zang lcag (zangs lcags) chasu (chas su) bcug/ la la stag gzid (gzigs) chasu (chas su) bcug/dung gi y+yar po (g.yar po?) dang/ g.yu'i thud (thugs) re dang/ s+yer (=gser) kis (gyi) ral+ri (ral gri) dang/lha'i rten du bzhag/ zang phags (=zangs phag) dmor (dmar po) g.y+yasu (g.yas su) btag/ bon gis (gyi) gto' yang byas/ dung myi mgo las zhal (=zha) phud pas/ wa spril (=sprel) grum pa'i g+ho la (=mgo la) bskon/ rkang las lham phud pa'i/ wa spril (sprel) grum pa'i rgang (=rkang) la rkon (=bskon)/ spril (=sprel) dang grum pa rnams/ dar zab chasu (chas su) bcud (=bcug)/ s+yer (gser) gis sgo mo dang/ g.yu'i sgo mo dang/ dngul gi sgo mo dang/ mchong gi sgo mo dang/ zangs+yi (zangs gyi) sgo mo dang/lcag (=lcags) gyi sgo mo dang/ bse'i sgo sga (=sgo) mo dang/ mda' gzhu' 'khor gsum dang/spril (=sprel) grum chasu (chas su) bcud (bcug)/ bon gis (gyi) sgyer yang sgyer (=gyer yang gyer)/ bslun (bslon) gyis rtsis kyang rtsis/zangs phags (phag) khra mo la/ glud mang dgu bgal/ spril (=sprel) bzhed lhags+si lhags (=lhags se lhags)/ wa 'gro dang lgis logs (=logs gyi logs)/ grum pas gtang skar (=skad) si li li/ bya 'phur dang lhabse (lhab se) lhab/ phag skad tse re re/

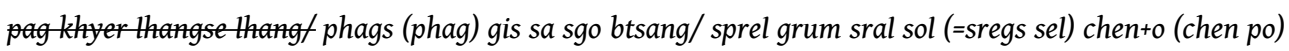
byas/ du ba gnam du song pa'is/gnam gi sgel 'ung (=sge khung) btsang/ mud+no dal (=bdud gyi mda') lam bcod/ me lce par (=bar) du 'dren pa'i)/[...].

46. The full title is rNam par dag pa'i 'bum bzhi las rin po che gnyan gyi 'bum bzhugs so. It constitutes the entirety of volume 78 , containing 165 folios, arranged into 26 chapters $\left(l e^{\prime} u\right)$. The number of the myths greatly exceeds the number of chapters (i.e., 26). While some of the chapters contain only one myth, some of the chapters are self-contained collections of often brief rabs. This 
version has been subject of an article by Samten G. Karmay, who introduced it and translated part of one of the myths it contains (Karmay 2010).

47. Its full title is Nye lam sde bzhi'i gnyan 'bum bzhugs pa'i dbus phyogs legs swo, and it constitutes a relatively small part of vol. 253. See gNyan 'bum, Katen 253-25, pp. 603-635.

48. The full title is 'Phen yul rgyas pa gnyan gyi 'bum bzhugs stho. The photographs of this manuscript version were taken in Amdo, Thewo region (The bo) by Ngawang Gyatso (Ngag dbang Rgya mtsho), a lecturer at Lanzhou University. I am indebted to him and to Charles Ramble who kindly made it available to me.

49. A quite interesting fact is that the Gyake beings listed in the text include Kuchi Mangke (Ku byi mang ske), a character known from other Tibetan myths and in a different context.

50. He is interestingly introduced in the language of Nam pa lDong. lDong is apparently name of an old clan (one of so called "six ancestral clans of Tibetans"), which is often associated with the deity Machen Pomra. The name of this ritualist is given as rDab lte lcags po in the given language of Nam pa lDong and as Ya ngal gyim gong in Tibetan. This ritual specialist is mentioned in number of sources as a specialist on purification rituals in the Tibetan version of his name. For interesting details concerning the mythical priest Ya-ngal see Huber 2013, pp. 269-280.

51. At the third month of spring he performed a purification with the blood of a lcog chung 'gyar $b a$ (perhaps a bird related to the skylark, co ga), a kite ('ol pa) and a duck (ngur pa). During the third summer month, he purified the pollution with the blood of a white crane (khrung khrung dkar po), a cuckoo ( $k h u$ byug) and a sandpiper (mthil=thing ril). In the third autumn month, he purified the pollution with the blood of spyang gshen bong ba, gdang bu and ju ru ye. During the third winter month, he offered the blood of a skylark (co ga), khrab bzhi skyes and sbang bya. Then he made 13 sheds from brushwood and "milked the wish-fulfilling cow" ('dod 'jo ba bzhos, pp. 10-11).

52. The Tibetan text reads (NB: 11): srid pa wa bu thung zhig bzang (=bzung)/ rgyab gser lcam (?lcags) ral gris bkral/tshangs pa lhas gsol (=lha sel?)/ rma de sha bra dang sgo sman ri gnyis/lcam dral mkhon bu sbyang/ mnol dang sme mkhon sbyangs pa de nas srid/ sku bla rma chen yul du gshegs/.

53. First, she is also mentioned as rGod lha ri mo (i.e. sGo should be rGod) at another point in the text. Secondly, after death women could become sman in the old texts. Thus, instead of Lha ri [mo] we would have here sMan ri [mo].

54. The wording of the translated part mentioning the fox is also uncertain. This part is somehow repeated in the text (the context is even less clear than in this case); in the present case it could be translated in the following way: "He caught a small fox of creation and ripped open his back with a golden razor. The poison of the gods was removed. The provision of restoration was released". (NB: 14-15) Srid pa wa bu thung zhig bzung/ rgyab gser gyi gtsags bu bkral/ lha dug phyung ngo/ gsas (? gsos) byed dkrol lo/.

55. These animals are also strikingly associated with the "wind horse" (rlung rta/klung rta), being depicted in the corners of "wind horse flags". Samten G. Karmay has argued that the yak was replaced at a later time, and following the myth of the origin of the Tibetans he demonstrates that these animals represented the original clans of Tibetans. In the light of the present text they seems to be animals representing the original layers of the vertically viewed world represented by Nyen beings. Even according to the myth translated and dealt with by Karmay, these animals were given to the clans of Tibetans by Nyen (see Karmay 1998b).

56. The text is full of spelling mistakes and contractions of words. It reads: gnyan bya khrung+ng (i.e. khrung khrung) khyung gos mo (i.e. gong mo) gsum/ srid pa'i zha (i.e. wa) grum rngosu (dngos su) bzung. The ways of writing letter zha is rather similar to wa in this particular manuscript and it should be oviously correctly wa - fox.

57. The Tibetan text reads: srid pa'i wa bsang dar gi rgyan/ rngul (=dngul) gyi dri'u (=dril bu) 'gul du btag/ ribs (ri rab) rtse skyal (=rgyal) srid pa tshangs/. I assume that the phrase known from the 
translations from Indic text ri rabs rtse rgyal could be also understood in the given reading of the text as: "the creation accompanying the top of the Excellent Mountain".

58. The Tibetan text reads: sngo+yi (sngon gyi) myil (myi rgyal) thang pos 2 (gnyan) bcos yags/ lha sgo phye bas dur sgo bcad/ sme mnol wa'i bsang/ sn+ring+d (snang srid) stong khams 'khrug pa phye (=bcad?) byang?)/ 2+pyi (gnyan gyi) mnol bsang de ltar yag/ da yang yon+da (yon bdag) 'di la de dang 'dra/ de gtsang ma'i wa bsang 'di/ klun (klu gnyan) sa (sa bdag) t+yod (gtod) 'khor rnam la 'don/ mnol ba wa'i tshang mdzad cig/ ('Phen yul rgyas pa gnyan gyi 'bum, fol. 16b-17a).

59. The Tibetan original apparently contains several misspellings, which are not amended in the following text. The text reads (p. 631): sa bdag klu gnyan yis ri bo mthon po'i drung du song ba la/ mchod pas na tshogs dang shing rtsi sna tshogs mang du sba/ bsnga shu grangs sam bya/ wa dang kham ma grum pa dang/ ba ra 'gar sogs pa dang/bsang dang dug phyung byas/ [...].

60. For this reference and summary of the literature dealing with incest in Tibetan societies see Buffetrille 2004 and 1998. See also Childs 2006.

61. I am indebted to Charles Ramble for pointing this out. See Ramble 1998, fn. 4.

62. Tib. [...] sa bdag gi lto bar phrad pas sa bdag yul lha thams cad la mi gtsang ba'i grib phog nas 'khrugs pas rgyal po dang yul khams thams cad du mi bde ba byung ba/.

63. It would also be interesting to explore in greater detail the Dunhuang document PT 1134, in which the fox figures along with the otter, the bird and the fish. They swear an oath, but because it is not honoured various unfavourable circumstances appear. The situation is then remedied by a ritual during which the portal of sky is opened, among other things. For pointing out this document I am indebted to Toni Huber who also shared with me his notes and comments on this passage. The Mongolian versions and their Tibetan counterparts from lDong khrom ( $m D a$ ' tshang) also speak about a similar motif of a promise being forgotten by the fox, resulting in pollution that is eventually removed by the ritual.

\section{ABSTRACTS}

The paper examines the previously neglected textual representations of a rather unusual ritual tradition of burning foxes. Similar Mongolian texts have been already discussed by a number of scholars and it is pointed out in this paper that these Mongolian texts bear clear signs of being translated from the original Tibetan. The paper deals with recently published corpus of texts from Dongtrom (lDong khrom) or Datshang ( $\mathrm{mDa}^{\prime}$ tshang) in Amdo, where some five Tibetan versions related to Mongolian works appear. Three other Tibetan texts are then discussed. The frequent mention of Nyen beings (gnyan) and the mythical priest Nyen Bon Thangthang Drolba (gNyan bon Thang thang sgrol ba) nevertheless points to the Nyen Collection (gNyan 'bum) as a principal textual source providing the context of the tradition.

Cet article étudie des représentations textuelles précédemment négligées d'une tradition rituelle assez inhabituelle consistant à brûler un renard. Des textes mongols similaires ont déjà été discutés par un certain nombre de chercheurs et cet article souligne le fait que ces textes mongols sont, de manière évidente, des traductions d'originaux tibétains. Cet article traite d'un corpus de textes récemment publiés provenant de Dongtrom (lDong khrom) ou Datshang (mDa' tshang) en Amdo, parmi lesquels se trouvent cinq versions tibétaines apparentées à des versions mongoles. Trois autres textes tibétains sont également discutés. La mention fréquente des êtres nyen (gnyan) et du prêtre mythique Nyen Bon Thangthang Drolba (gNyan bon Thang thang sgrol 
ba) désigne néanmoins la Collection nyen (gNyan 'bum) comme la source textuelle principale fournissant le contexte de la tradition.

\section{INDEX}

Mots-clés: renard, bon, Tibet, Amdo, rituel, sacrifice

Keywords: fox, Bon, Tibet, Amdo, ritual, offering

\section{AUTHOR}

\section{DANIEL BEROUNSKÝ}

Daniel Berounský is associate professor at the Department of South and Central Asia, the Faculty of Arts and Philosophy, Charles University in Prague. His published research focuses on indigenous rituals in Tibet, case studies of spirit-mediums in eastern Tibet, selected problems of Tibetan history and Tibetan ideas associated with the afterlife.

Daniel.Berounsky@ff.cuni.cz 